\title{
Revival of Traditional Cascade Tanks for Achieving Climate Resilience in Drylands of South India
}

\author{
Pennan Chinnasamy ${ }^{1,2,3 * \neq}$ and Aman Srivastava ${ }^{1+\neq}$ \\ ${ }^{1}$ Centre for Technology Alternatives for Rural Areas, Indian Institute of Technology Bombay, Mumbai, India, ${ }^{2}$ Rural Data \\ Research and Analysis Lab, Indian Institute of Technology Bombay, Mumbai, India, ${ }^{3}$ The Interdisciplinary Programme in \\ Climate Studies, Indian Institute of Technology Bombay, Mumbai, India
}

\section{OPEN ACCESS}

Edited by:

Tibor Stigter,

IHE Delft Institute for Water

Education, Netherlands

Reviewed by:

Supriyo Chakraborty,

Indian Institute of Tropical Meteorology

(IITM), India

Alemseged Tamiru Haile,

International Water Management Institute, Ethiopia

*Correspondence:

Pennan Chinnasamy

p.chinnasamy@iitb.ac.in

tThese authors have contributed equally to this work

¥ORCID:

Pennan Chinnasamy orcid.org/0000-0002-3184-2134 Aman Srivastava orcid.org/0000-0001-9253-3485

Specialty section:

This article was submitted to

Water and Climate,

a section of the journal

Frontiers in Water

Received: 09 December 2020 Accepted: 23 March 2021

Published: 22 April 2021

Citation:

Chinnasamy $P$ and Srivastava $A$ (2021) Revival of Traditional Cascade Tanks for Achieving Climate Resilience

in Drylands of South India.

Front. Water 3:639637.

doi: 10.3389/frwa.2021.639637
Traditional tanks in arid regions of India have been working to address water demands of the public for more than 2000 years. However, recent decade is witnessing growing domestic and agricultural water demand coupled with rising encroachment and ignorance toward tanks; consequently, intensifying water shortage issues. While climate change is impacting at alarming rates, local agencies have forgotten these tanks that have aided in sustainable water supply solutions for decades apart from municipal water supply. This research, for the first time, estimates water supply-demand for an arid region in South India (Madurai) and lists out the benefits if tanks were managed and desilted. Exploratory investigations for documenting seasonal domestic and agricultural unmet water demand were conducted followed by their validation through ground-truthing across the study period 2002-2019. Results indicated high unmet domestic water demand, estimating 73\% [maximum 365 thousand cubic meters (TCM)] for summer (March to May) and 33\% (maximum 149 TCM) for winter (January and February), and high unmet agricultural water demand estimating 90\% (maximum 5,424 TCM) during North-East monsoon (October to December), and 95\% (maximum 5,161 TCM) during South-West monsoon (June to September). Erratic rainfall pattern was identified as a major cause for higher fluctuations in water availability inside tanks ranging 0-50\%, while lack of ownership resulted in increased siltation load ranging $30-70 \%$ of the tank's volume. The study found that the major portion of the unmet water demand can be accounted for through rehabilitation of the tanks, as under the rehabilitated tank irrigation scenario the tank storage could attain $200-400 \%$ more water than the estimated agricultural water demand. It was concluded that if the cascade tanks were managed appropriately, they could have positive impacts by reducing floods and providing water for drought seasons.

Keywords: sustainable development, groundwater, tank cascade systems, tank irrigation, water security, climate resilience, arid watershed management

\section{INTRODUCTION}

In order to meet the targets of Sustainable Development Goal 6 (SDG 6), it is essential to overcome the challenges for attaining surface and groundwater security and sustaining adequate water supply, especially in the countries that are under-developed or developing (Chinnasamy and Prathapar, 2016; Benson et al., 2020; Chinnasamy et al., 2021). Water scarcity in the arid and semi-arid regions in such countries 
has continued to enforce rural-household members, more specifically the female members including school-going children, to fetch water from distant sources (Nauges and Strand, 2013; Komatsu et al., 2019). Additionally, considerable impacts of the demographic explosion, rapid urbanization, over-exploitation of surface and groundwater resources, and changing climate and associated vulnerabilities have further endangered the safe, secure, and adequate water supply in developing countries such as India (Vörösmarty et al., 2010; Chinnasamy and Hubbart, 2015; Habeeb et al., 2019; Saraswat et al., 2019; Chinnasamy and Parikh, 2020). Besides enabling water security provisions by considering the water demand-supply factors, the climate is yet another crucial factor impacting the water balance, thereby water supply potential of the watershed or catchment (Mehran et al., 2017; Erfani et al., 2018). Hydrological phenomena such as evaporation and evapotranspiration undergo drastic changes as a result of the rise in temperature mostly attributed to global warming. This subsequently results in a potential change in the frequency, intensity, and magnitude of the monsoonal rain, thereby severely impacting the available water resources (Kumar et al., 2017; Bonfils et al., 2020). In the global context, past studies have substantially reported that the primary reason behind the restricted economic development, more specifically in the developing countries, is the rising water demand, which is causative to water scarcity (Liu et al., 2017; Chinnasamy et al., 2018; Greve et al., 2018; Boretti and Rosa, 2019; Chinnasamy and Shrestha, 2019). According to the reports of the International Food Policy Research Institute (IFPRI), more than 2.4 billion people $(\sim 36 \%)$ are witnessing the ill-impacts of water scarcity in the ongoing decade (IFPRI, 2012). In addition, $\sim 22 \%$ of the Gross Domestic Product (GDP) are produced globally from these water-scarce regions. Studies have predicted that by 2050 , the global population might attain a magnitude of 10 billion (United Nations, 2005) and that the GDP will increase 4fold as compared to the ongoing decade (OECD, 2012). This demographic explosion will increase the food demand by $70 \%$ which will markedly increase the agricultural water demand by several folds (FAO, 2009). Additionally, it is also predicted that by 2050 , around $70 \%$ of the population will be located in the urban belts with changed socio-economic conditions, living standards, and water consumption patterns (FAO, 2009). One of the impacts of improved lifestyle has been reflected on the water demand which has been predicted to increase by $55 \%$ by 2050 (OECD, 2012; Wang et al., 2016). These changes will severely stress the water resources systems and would make it challenging to maintain sustainable water supply-demand management schemes, especially for agricultural, domestic, and industrial water use. For example, studies have shown that by 2050 , the projected population at the risk of hunger will range from 10 to 20\% (Parry et al., 2009; Godfray and Garnett, 2014), while more than $52 \%$ of the global population including $45 \%$ of the global GDP would be under severe water scarcity threat (IFPRI, 2012). Current water supply practices to meet the everincreasing water demand seem inadequate to combat climate change impacts in terms of unprecedented and flash floods and recurrent and chronic droughts (Miller and Belton, 2014; Lindersson et al., 2020). Hence attempts to formulating water supply-demand schemes with existing water infrastructures require further attention toward improvisation in meeting unmet (deficit) water demand considering sustainability, efficiency, and security in supply facets.

India, which is one of the developing and emerging economies is also not exempted from the misbalance between the water availability, water demand, and potential to provide water supply adequately to the $\sim 1.4$ billion people ( $18 \%$ of the world's population). The total average flow of the surface water resource in India is around 1952.87 billion cubic meters (bcm) annually (4\% of the world's water resources), of which utilizable surface water resource is a mere $690.32 \mathrm{bcm}$ annually (MoJS, 2019). It has been estimated by the Central Water Commission (CWC) that in order to store the utilizable surface water flow, storage capacity as high as $490 \mathrm{bcm}$ would be required (CWC, 2019). However, the available surface water storage potential in India is close to $253 \mathrm{bcm}$, which is almost half of the actual storage requirement (Subramanya, 2013). Furthermore, according to the findings on future water supply-demand scenarios from the reports of the National Commission for Integrated Water Resources Development (NCIWRD), it has been estimated that the annual domestic water demand from the surface water resources, which is currently $24 \mathrm{bcm}$, will sharply increase to 36 bcm (50\% increment) by 2025 and $65 \mathrm{bcm}$ (171\% increment) by 2050 (MoWR, 2014). While for the same study period, the annual agricultural water (irrigation) demand from surface water resources, which is currently $339 \mathrm{bcm}$, will increase to 366 $\mathrm{bcm}$ ( $8 \%$ increment) and further to $463 \mathrm{bcm}$ (37\% increment), respectively (Subramanya, 2013; MoWR, 2014). On the contrary, the residual utilizable surface water resources (the volume of water left after satisfying water demands) will face a sharp decline against the rising sectoral water demand from the current 284 to $219 \mathrm{bcm}$ by 2025 ( $23 \%$ decrement) and further to $42 \mathrm{bcm}$ (85\% decrement) by 2050 (Subramanya, 2013; MoWR, 2014). It can be inferred from the aforementioned findings that the available surface water resources are inadequate to meet the rapidly rising water demand up to the year 2050 indicating the distressing foreseeable water supply-demand scenarios. Hence, developing robust water management strategies facilitating last-mile connectivity for achieving domestic and irrigational requirements is the current need of the time.

In order to combat mismanagement in water supplydemand facets under the Indian context, holistic approaches to conservation efforts on the supply-side using available water infrastructure such as check dams, lakes, ponds, tanks, etc. along with reducing water requirements on the demand-side is needed. Providing individual access to water sources for drinking, domestic, irrigational, and other needs are considered fundamental to water security (Government of India (GoI), 2020). Enabling water security is essential to overcome the water crisis, thereby water imbalances, however, prior to developing strategies for water security, it is imperative to measure and estimate the water budget given water supply, demand, and output in a catchment or micro-watershed (Chintalapudi et al., 2017; Agarwal et al., 2019). Such exercises via ground-truthing provide precise estimates about water deficiency or surpluses. Water deficiency, in turn, can indicate the unmet water 
demand in water-consuming sectors while water surpluses may indicate flash flood events or poor management of surplus water which may be flowing away as surface runoff (Srivastava and Chinnasamy, 2021a,b). Establishing social, economical, and political systems coupled with strengthening the institutional network toward water resources management provide scopes to achieve water security (Wilk and Jonsson, 2013; Basu et al., 2020). Additionally, participatory approaches for managing commonpool resources are yet other effective approaches identified that can provide sustainability via strategizing water security plans (Kirono et al., 2014; Government of India (GoI), 2017). There is thus also a need to understand water security issues from the perspective of surplus or unmet water demand across arid regions of a developing country such as India, wherein water supply is coupled with decentralized institutional arrangements to managing supply-demand facets.

Given the background of attaining water security in water supply-demand and SDG 6, several schemes and programs have been launched at a national scale in India. For example, previously, the Central Government used to provide financial and technical assistance to the State Government under their schemes such as the Accelerated Rural Water Supply Programme (ARWSP) of 1972 and Rajiv Gandhi National Drinking Water Mission (RGNDWM) of 1986. However, by the beginning of the 21st century, a paradigm shift was observed in the role of the Government from being an assistant to a facilitator. For example, the Swajaldhara development project of 2002 was among the first scheme that aimed for a people-centric approach in water management for attaining self-sufficiency in the rural water supply (Government of India (GoI), 2002). Similarly, the National Rural Drinking Water Programme (NRDWP) of 2009 (Government of India (GoI), 2010), which has been restructured and subsumed into the Jal Jeevan Mission (JJM) in 2020 are a couple of the recent attempts being taken by the Government of India, wherein the scheme aimed toward provisioning individual household tap connections by 2024 (Government of India (GoI), 2020). Meanwhile, in order to devise cost-effective demanddriven water supply strategies, the Government of India released policy guidelines titled National Action Plan on Climate Change (NAPCC) in 2008 followed by the State Action Plan on Climate Change (SAPCC) in 2010. The overall objective of NAPCC and SAPCC, given achieving last-mile connectivity for water access under climate change, was to improve the adaptive capacity of the users to combat the negative impacts of future climate change on water demand (NAPCC, 2008; SAPCC, 2010). Nevertheless, due to varying geologic, hydrologic, and climatological conditions across India, implementing national-scale policies on a local scale could be challenging. This demands attention toward developing site-specific, decentralized, and efficient water supplydemand strategies by conducting case-by-case field investigations aiming to determine actual water demand against actual water availability across different seasons.

Besides the schemes focusing on last-mile connectivity, rainwater harvesting vide surface storage structures are yet the other focus of the Government in India given incapacitating the challenges of water security (Government of India (GoI), 2019). The water harvesting structures such as tanks, ponds, lakes, etc. have been traditionally used, especially in the rural context, owing to widespread agricultural practices. These structures were created so as to facilitate rainwater storage during the monsoon season followed by its diverse applications across the non-monsoon seasons (Glendenning et al., 2012; Reddy et al., 2018; Bhattacharjee, 2019). One such structure among them is the tanks, designed and constructed about 2,000 years ago, as a result of the extraordinary engineering and managerialsocial skills of the rulers, philanthropists, and local communities (Balasubramanian and Selvaraj, 2003; Palanisami, 2006). Tank cascade systems dominated particularly in arid and semi-arid regions of Southern India due to the erratic rainfall pattern and poor potential for groundwater extraction. Tanks across their network have been known to facilitate groundwater recharge, irrigate cultural command areas, meet domestic and livestock water needs, and mitigate negative consequences of flash floods and long spells of droughts. Additionally, these system tanks provided water security, especially during the acute water crisis in the non-monsoon seasons or drought periods (Molden et al., 2003; Bebermeier et al., 2017). The application of tanks for multiple purposes remained widespread and popular until the beginning of colonial rule (early 19th century). Institutional arrangements remained in place to protect and sustain these tank systems for several centuries. However, these age-old systems, due to unwarranted political interventions and changing socioeconomic dynamics from the colonial rule, have resulted in their degeneration, which continued until the 1980s in independent India. Nonetheless, after realizing the significance of the tank cascade system in the context of surface and groundwater security, several revivals, and rehabilitation measures and programs were launched in various South Indian states such as Tamil Nadu, Andhra Pradesh, Karnataka, and in recent times in the Telangana State (Reddy et al., 2018). In this state of affairs, it becomes imperative to investigate the implications of past and modern anthropogenic actions on the functional tank cascade system in the baseline of water supply-demand arrangements given water security as the foremost priority.

The present study thus investigated one such cascade system in the Madurai district of the Indian state of Tamil Nadu located in the Southern-peninsular region. The tank system is popularly named as Vandiyur tank cascade system (VTCS), wherein eight system tanks were observed interconnected through their surplus streams across rural, peri-urban, and urban regions of Madurai city. Preliminary investigations revealed that the cascading network underwent severe degeneration and at the same time drinking and domestic water requirements of the residents settled in the vicinity of these tanks were experiencing a water crisis. On the account of the initial findings from the preliminary field survey, it was decided to investigate catchment-wise domestic and agricultural draft, imbalance in water supply-demand, and key reasons for the water scarcity across VTCS. Under these settings, the major objectives of this study were identified as (1) to estimate the domestic water demand by investigating the latest human population; agricultural water demand by investigating the culturable command area; catchment-wise unmet water demand for both domestic purposes by measuring municipal water supply and agricultural purposes by quantifying 
tank (cascade) water supply; (2) to develop water security and management plans and provide recommendations to the government authorities, policymakers, and local Water User Associations (WUAs) regarding the placement of the appropriate local mechanisms for achieving water security. The water security plans, in the present study, intended to cover strategies that supposedly protect available water resources from threats of climate change impacts such as floods, droughts, and undesirable losses occurring as a result of water mismanagement in the VTCS. It was hypothesized that water security plans intending toward water supply-demand can strengthen the initiatives toward achieving better water management in the vulnerable catchments in view of water scarcity pertaining to critical dry seasons. It is expected that the findings from the present case study will provide baseline information to the policymakers and development authorities to improve their understanding of supply-demand management in the context of traditional water management practices using tank cascade systems.

\section{METHODS}

\section{Study Area}

Madurai city is part of the Madurai corporation and represents the administrative headquarter of the Madurai district in the Indian state of Tamil Nadu (Figure 1A). The archaeological findings suggest that the district is more than two millennia old and continuously inhabited (Alaguraja et al., 2010). Madurai city, which is also known as the cultural capital of the state, is located between $9.93^{\circ} \mathrm{N}$ and $78.12^{\circ} \mathrm{E}$ with an average elevation of 101 meters above mean sea level. As there are no hills in the region, the city experiences roughly steady-state meteorological conditions. However, as the Tamil Nadu state is located in the semi-arid climatic zone, the city, at the same time, also experiences a dry-summer subtropical climate (Bal et al., 2016). The Madurai city receives a mean normal rainfall of $930 \mathrm{~mm}$ while the mean actual rainfall in 2018 was recorded $734 \mathrm{~mm}$. North-East monsoon is the principal rainfall season followed by South-West monsoon. The temperature ranges from 15 to $41^{\circ} \mathrm{C}$ while the relative humidity ranges from 45 to $85 \%$ in the Madurai district (Central Ground Water Board (CGWB), 2008). The geological formations range from Archean to recent and include the Khondalite, Charnockite, and Garnitiferous Granulite Biotite Gneisses, Fissile Hornblende Biotite Gneisses group of rocks. The groundwater occurs from semi-confined to confined aquifer conditions in deeper fractures and is interconnected by fractures (Central Ground Water Board (CGWB), 2007).

The study site VTCS is located in Madurai city and it extends from Vandiyur village located in Madurai-urban on the left bank of the Vaigai river to the Kulamangalam village in the Madurai-rural region. The study site was categorized into six catchments $(C)$ where each one was representative of at least a system tank (T) of VTCS, wells $(W)$, and agricultural land apart from the human settlement (Figure 1B). These catchments were further classified into three types based on their developmental settings. First, the villages Kulamangalam (C1) and Veerapandi (C2) under "Madurai-rural" each consisted of the tanks T1 and
T2. Second, Thiruppalai (C3) and Siruvour (C4) under "Maduraiperi-urban" each consisted of the tanks T3 and T4. Third, Kosakulam-Parsurampatti-Kodikulam (KPK-C5) and Vandiyur (C6) under "Madurai-urban" each consisted of the tanks T567 and T8. A gentle slope from $C 1$ to $C 6$ was observed that caused gravity flow thereby interconnecting $T 1$ to $T 8$ via series of the tanks along VTCS (Figure 1C), wherein the surplus runoff from one tank recharged the next tank located downstream and so on until T8 discharges into Vaigai river at the most downstream (Figure 1B).

\section{Fieldwork and Data Collection Sources}

The present study followed the embedded design of the mixed methods research encompassing both field (primary data collection) and technical (secondary data collection) aspects, inclusive of quantitative (data-based) and qualitative (surveybased) research methods (Creswell and Clark, 2007; HesseBiber, 2010). In this research framework, the data obtained from qualitative investigations were the primary source while quantitative and statistical analysis of the secondary data sources were used as supportive data. Field investigations were conducted between November 2018 to January 2020 to contemplate temporal findings from four seasons ( $\mathrm{t}$ ) viz., winter (January and February having 59 days), summer (March to May having 92 days), S-W monsoon (June to September having 122 days), and N-E monsoon (October to December having 92 days). The tanks $(T 1-T 8)$ and wells $(W 1-W 22)$, located across each of the interconnected catchments $(C 1-C 6)$, were visited. The volumes of the hydrological and supply-demand parameters were estimated for each season in units of a thousand cubic meters (TCM or $1,000 \mathrm{~m}^{3}$ ). As the study area comprised of varying developmental settings (rural, peri-urban, and urban), primary data collection was made via a case-by-case basis in order to develop catchment-specific narratives for rainfall patterns, municipal water supply, tank-fed irrigation, and groundwater fluctuations. Finally, the data gathered, as a result of the aforementioned exercise, were analyzed using the embedded design of mixed methods research.

\section{Participatory Rural Appraisal in Rural Catchments}

The primary data across rural catchments (C1 and $C 2)$ were collected by conducting Participatory Rural Appraisal (PRA) (Chambers, 1994). In addition, personal communication with the officials of active NGOs, such as DHAN Foundation who have been conducting PRAs and training programs across rural catchments since the 1990s, was also included (Elamuhil, personal communication, 28-30 December 2019). PRA activities primarily included focused group discussions (FGDs) based on Merton (1987, 2008), semi-structured interviews, and community observations, which were used for data gathering. These activities were conducted with the Sarpanch (village head or Talaivar), Gram Sevak (village development officer), members of GP, farming, fishing, and animal rearing communities, and local villagers. The FGDs were conducted with adult members (age $>18$ years) in two phases attracting participation from both men and women (sample size $N=45$; comprising $65 \%$ males and $35 \%$ females). The two FGDs were scheduled across two 


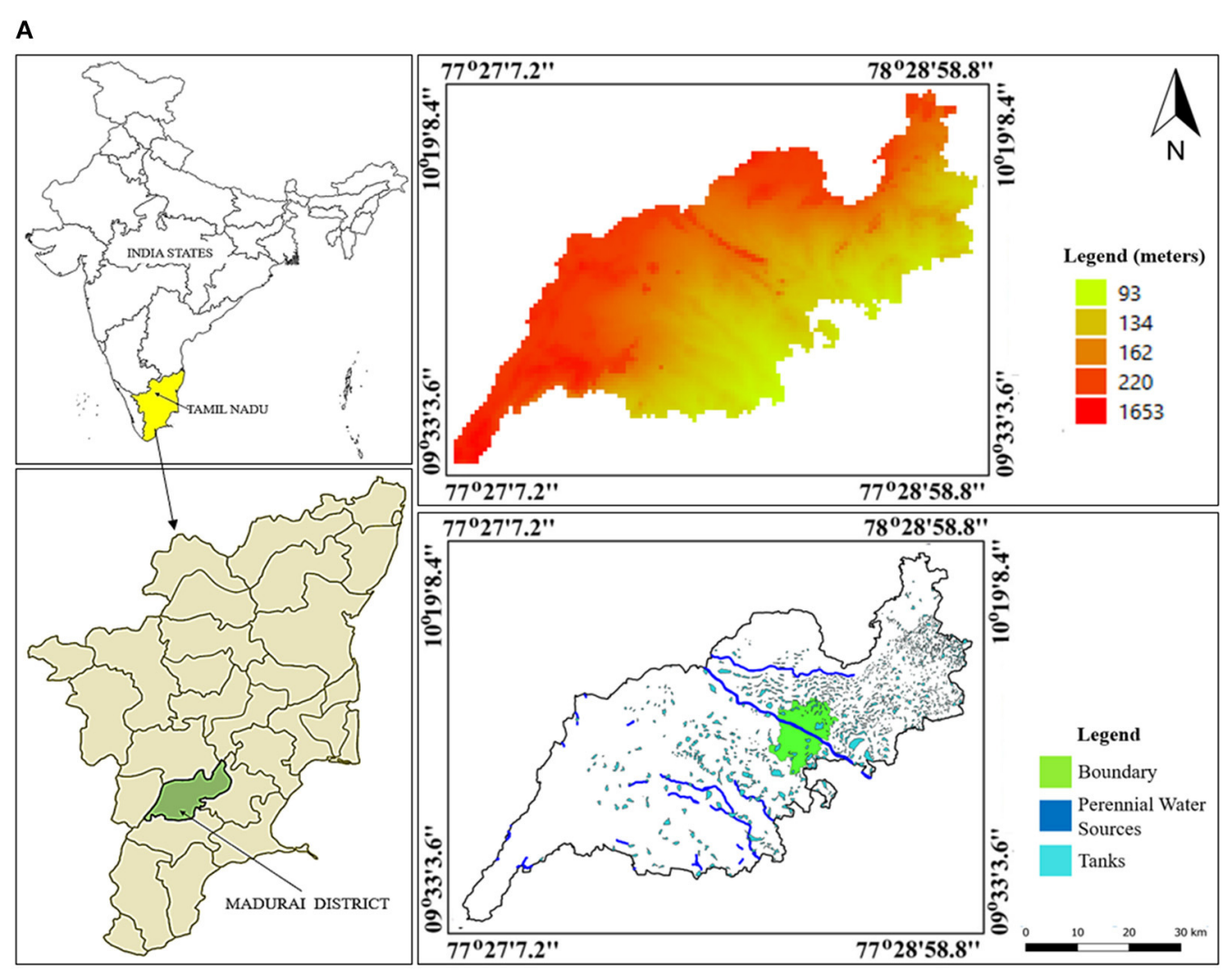

B

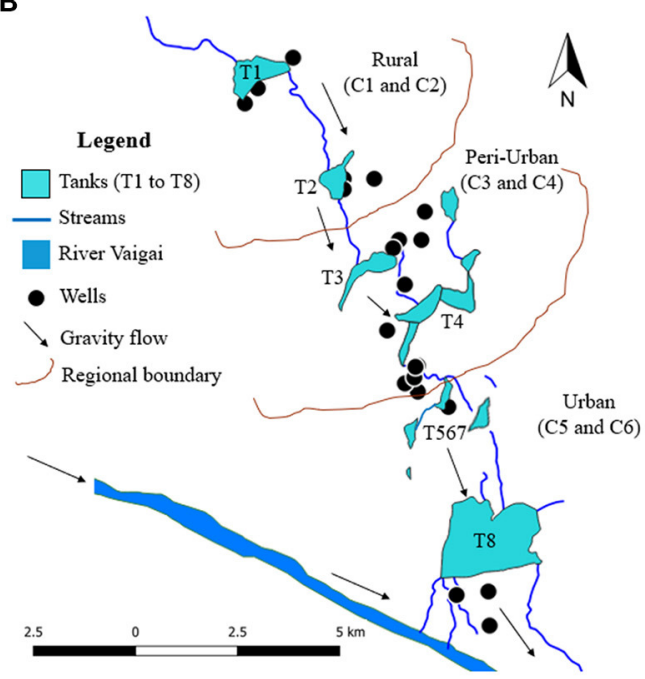

C

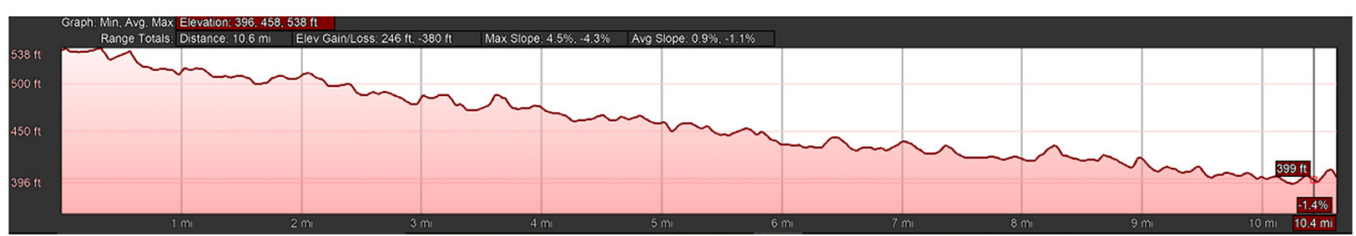

FIGURE 1 | Study area: (A) Location of study site in Madurai district, Tamil Nadu, India (Inset shows the location of Madurai in India and the Digital Elevation Model (DEM) of Madurai), (B) Location of tanks (T1-T8) and wells (W1-W22) in catchments (C1-C6), and (C) Google Earth elevation graph from village Kulamangalam (North) to Vaigai river (South) [C1: Kulamangalam; C2: Veerapandi; C3: Thiruppalai; C4: Siruvour; C5: Kosakulam- Parsurampatti- Kodikulam; C6: Vandiyur]. 
different periods viz., one at the interface of summer and S-W monsoon while the other at the interface of N-E Monsoon and winter. Phasing of FGDs in two different seasons $(\sim$ summer and $\sim$ winter) allowed to document a common understanding of the various physical and social aspects of water resources, associated supply-demand management structures, and domestic and livestock water requirements in the villages. Yet another focus via FGDs was on the agricultural pattern adopted in the villages including cropping pattern, selection of crops, number of cropping seasons practiced, and key challenges in acquiring irrigation water from the sources such as tanks and wells. Semi-structured interviews followed snowball sampling for selecting the interviewees. The broad topics which were discussed under FGDs were narrowed down during interviews to collect individual preferences and perspectives regarding the tank irrigation and rainfed-based irrigation, potential of wells and tanks in meeting their agricultural water demand, impacts of the monsoonal rainfall on the productivity of agriculture as well as on functionalities of tanks, and consequences of (if any) floods or droughts due to extreme climatic events in the past. Community observations followed a non-participatory based data gathering process, wherein multiple-usages of the tanks in the rural-context were recorded.

\section{Qualitative Investigations in Urban Catchments}

Stratified random sampling was used for conducting the household survey in peri-urban (C2 and C4) and urban catchments ( $C 5$ and $C 6$ ) for the age group of 20-70 years. On average 40 respondents were selected from each urbanized catchment comprising $60-70 \%$ males and $30-40 \%$ females. In addition, personal communication with the officials of active NGOs, such as DHAN Foundation who have been conducting surveys with households in the vicinity of tanks under VTCS, was also included (Elamuhil, personal communication, 28-30 December 2019). Discussion from other tank user and welfare associations such as Gomathipuram Associations and Walkers Club, particularly working for improving the status of one the largest tank under VTCS viz., Vandiyur tank (T8) was conducted. The surveys primarily aimed at documenting further insights regarding drinking and domestic water requirements and agricultural needs, in line with the questionnaire as was prepared under semi-structured interviews for rural catchments. Additionally, it further emphasized seeking propositions on devising water supply-demand management plans, given anthropogenic stresses and climate change implications on municipal and tank water supply potential.

\section{Reconnaissance Surveys, Field Investigations, and GIS Mapping Across VTCS}

The study conducted reconnaissance surveys followed by detailed field surveys and experimentations across catchments with the purpose to determine interconnectedness and current functionalities of systems tanks under VTCS. The oral history factor was used to record the generational changes in tank storage as well as the seasonal fluctuations in water level inside the tank water spread area (detailed in section Estimation of Tank Storage Capacity). The data for municipal domestic water supply were obtained from the secondary sources (District Profile, 2016); however, to determine the seasonal flow rate of water being supplied to household taps, household surveys additionally included experiment of measuring flow rates of the running tap across winter, summer, S-W monsoon and N-E monsoon seasons. Following this, respondents were enquired about the number of hours for which municipal water is being supplied across a day. This exercise allowed estimating the volume of water provided [based on the simple multiplication of flow rate $\left(\mathrm{m}^{3} / \mathrm{h}\right)$ with duration for which water is being supplied in a day (24h)] by the municipal corporation across each season against the actual domestic water demand. Furthermore, the active wells located in the vicinity of tanks were selected and depth to water extraction level were monitored across four seasons viz., the NE monsoon in 2018, winter, summer, and S-W monsoon in 2019. In addition, primary data, as collected by the DHAN Foundation, for groundwater wells from across different areas of VTCS were also used as supportive data. Besides this, in order to develop a long-term understanding of the annual fluctuations in the depth to groundwater levels, oral history factor was used based on the replies of the respondents during semi-structured interviews, household surveys, and personal communications (Elamuhil, personal communication, 28-30 December 2019). The depth to groundwater extractions for the years 2003, 2008, and 2018 was determined by quantifying the responses of the interviewees and by seeking information on the length of the pipes installed inside the ground for extracting groundwater and maintenance investments made since 2002 in view of the increasing length of the pipes for extracting groundwater.

The data on the depth to groundwater extraction were obtained for the 22 well points unevenly spread across rural, peri-urban, and urban catchments along with their geographical coordinates and maintained in MS Excel files. To process these discrete data points for spatial visualization across VTCS, firstly, the format of the Excel files was converted into Comma-Separated Values (.csv format). This was followed by importing the spreadsheet into QGIS, wherein it was added as a spatial layer using a delimited text layer tool. Spatial interpolation was conducted using Inverse Distance Weighting (IDW) method that allowed to optimally estimate the values at those locations where no measurements were taken. The exercise generated a continuous map for depth to groundwater extraction; however, to visualize the groundwater extraction levels in their respective catchments, the shapefiles of the VTCS [having eight interconnected tanks (T1-T8)], as provided by DHAN Foundation Data Centre, were added as a layer in QGIS. The maps for depth to groundwater extraction for the years 2003 , 2008, and 2018 were developed and used for differentiating the potential of rural, peri-urban, and urban wells. This additionally provided information regarding plausible correlations between the status of the tanks and the wells located in the vicinity.

\section{Estimation of Seasonal Rainfall in Madurai City}

The purpose of involving rainfall analysis in this study was to understand the correlation between declining tank storage and 
irregularities in the water supply to meet the rising water demand with rainfall received across each season. The annual rainfall data, from 2002 to 2018, for the Madurai region were obtained from the India Meteorological Department (IMD). The study period was ascertained considering the expansion in the urbanization of Madurai city that peaked post-2000. In order to determine the seasonal impacts of the annual rainfall over VTCS regions, rainfall data were classified into four seasons viz., winter, summer, South-West monsoon, and North-East monsoon. Based on the definition of normal rainfall, which is defined as an average of the rainfall values over 30 years, the present study estimated normal seasonal rainfall based on the last 50-year rainfall data (1969-2018). The normal seasonal rainfall was compared with the average (actual) seasonal rainfall received between 2002 and 2018 so as to arrive at rainfall departures.

\section{Estimation of Domestic, Agricultural, and Unmet Water Demand}

The total domestic water demand was estimated based on the water consumption in rural/urban regions as per Indian Standard (IS) Codes - IS 1172: 1993 (IS 1172, 1993). The present study considered a demand of 50 liters per capita per day (Lpcd) in rural catchments while $100 \mathrm{Lpcd}$ and $150 \mathrm{Lpcd}$ for peri-urban and urban catchments, respectively. The population was obtained from the government source (Census of India, 2011), and the geometric growth method of population increase was used to arrive at the population of 2019 ( Pop $_{2019}$ ). The seasonal domestic water demand ( $\left.D_{\text {seasonal }}\right)$ was multiplied with the population of each catchment and the number of days in each season $\left(d_{\text {season }}\right)$ to arrive at the total domestic water demand $(D)$ using Equation (1).

$$
\mathrm{D}=\sum_{\mathrm{t}=1}^{\mathrm{t}=4}\left(\left(\text { Pop }_{2019}\right) \times\left(\mathrm{D}_{\text {season }}\right) \times\left(\mathbf{d}_{\text {season }}\right)\right)
$$

For determining total agricultural water demand $(A D)$, the household survey was conducted to obtain information on the cultivable land area holding $\left(A_{\text {crop }}\right)$. This study considered crop water requirement $(\Delta)$ for all Kharif (monsoon) and Rabi (nonmonsoon) crops (Allen et al., 1998) to estimate the seasonal crop water requirement individually for Kharif $\left(A D_{\text {kharif }}\right)$ and Rabi $\left(A D_{\text {rabi }}\right)$, as shown in Equation (2).

$$
\mathbf{A D}=\sum_{\mathbf{t}=1}^{\mathbf{t}=\mathbf{4}}\left(\left(\mathbf{A}_{\text {crop }}\right) \times(\Delta) \times\left(\mathbf{d}_{\text {season }}\right)\right)
$$

The unmet water demand was estimated as the difference between the total water demand in urban areas ( $\left.D_{\text {urban-season }}\right)$ or total water demand for irrigation purposes ( $\left.D_{\text {agricultural-season }}\right)$ and the water supply delivered $\left(W_{\text {supply }}\right)$ in each case. In the case of rural/urban catchments, the principal water supply source for agriculture was the tanks $\left(W_{\text {supply-tank }}\right)$ while the open wells remained the domestic water supply source in the rural catchments. Whereas, in the case of urban and peri-urban catchments, the municipal water supply ( $\left.W_{\text {supply-municipal }}\right)$ was the principal water supply source for domestic purposes. The volume of domestic unmet water demand in both peri-urban and urban catchments ( $\left.U D_{\text {domestic-urban }}\right)$ and the volume of agricultural unmet demand $\left(U D_{\text {agriculture }}\right)$ was estimated using Equations 3 and 4, respectively.

$$
\begin{aligned}
& \mathrm{UD}_{\text {domestic-urban }}=\sum_{\mathrm{t}=1}^{\mathrm{t}=4}\left(\left(\mathrm{D}_{\text {urban-season }}\right)\right. \\
& \left.-\left(\mathrm{W}_{\text {supply-municipal-season }}\right)\right) \\
& \mathrm{UD}_{\text {agriculture }}=\sum_{\mathrm{t}=1}^{\mathrm{t}=4}\left(\left(\mathrm{D}_{\text {agriculture-season }}\right)-\left(\mathrm{W}_{\text {supply-tank-season }}\right)\right)
\end{aligned}
$$

\section{Estimation of Tank Storage Capacity}

The surface area of the tank $\left(A_{\text {tank }}\right)$ was obtained during the site survey and the tank volume estimation was based on the average depth to full-tank level (FTL) of the tank. The data on the total volume of the tank was obtained from the district PWD office, while the actual volume was obtained by site survey of tanks. The field survey was conducted inside the tanks during the summer of 2019 when the structure was completely dry. The GPS (Global Positioning System) essential tool was used to identify the coordinates of all the points recorded while traversing in NorthSouth (N-S), East-West (E-W), NW-SE, and NE-SW directions. To analyze the seasonal tank capacity $\left(S_{\text {season }}\right)$, measurement of the depth to the water level in the tanks was conducted from January to December in 2019 in order to record the seasonal fluctuations in the water level. To get the estimates of the seasonal level of the water in the tank for the last couple of decades (post-2002), qualitative interviews were conducted with the local residents/communities in and around the tanks along with personal communication (Elamuhil, personal communication, 28-30 December 2019). The responses on the availability of the water in the tank across each season were quantified as a percentage (\%) Water Availability and the total volume of water inside the tank $(S)$ were calculated using Equation (5).

$$
\mathbf{S}=\sum_{\mathbf{t}=1}^{\mathbf{t}=\mathbf{4}}\left(\left(\mathbf{S}_{\text {season }}\right) \times\left(\mathbf{A}_{\text {tank }}\right) \times(\% \text { Water Availablity })\right)
$$

\section{RESULTS}

\section{Findings From Qualitative Surveys and Field Observations}

The qualitative and field investigation of VTCS during 2018-19 revealed that the tanks within VTCS were traditionally designed for irrigation and livestock management purposes. However, their functionality drastically changed in modern times. For instance, in rapidly urbanizing catchments, irrigation tanks were observed functioning as percolation tanks. Besides this, tanks were typically identified as rain-dependent (rainfall remained erratic, as discussed in detail in section Analyzing Seasonal Rainfall Fluctuations and Their Impacts on Madurai City) as a result of which the water supply for irrigation works remained highly unreliable. In most cases, the water level inside the tank water spread area was observed to decline rapidly by the end 
of winter and dried completely during the summer. On the other hand, the qualitative interviews from the local residents regarding the municipal water supply in urban and peri-urban catchments revealed its high inconsistency across the seasons. As a result, the groundwater resources, via borewells and tubewells, were observed as the primary source for drinking and domestic purposes. But the continual decline in the groundwater levels enforced the local residents to fetch water from distant sources, to remain dependent on tanker water supply, and to purchase water from the local distributors. In general, both surface and groundwater resources in the VTCS region were identified as vulnerable to climate changes and anthropogenic actions. A management strategy intending to combat the stress of everincreasing water demand on available water sources in varying developmental settings of Madurai city is required.

PRA and personal communications with communities settled in the vicinity of VTCS and officials of DHAN Foundation (Elamuhil, personal communication, 28-30 December 2019), respectively revealed their experiences of climate change and its negative consequences on agricultural productivity, allied livelihood activities, and mismanagement in the ongoing water supply-demand mechanism. Based on the discussions and observations, findings illustrated the presence of flash floods and recurrent drought events, which are occurring cyclically and alternatively for the last two decades across VTCS. As per the interview's experience, flash flood events with a high frequency occurred in the annual period of September to November while long-term and extended droughts occurred in the annual period of March to July since the year 2000. More empiric shreds of evidence were obtained from the oldage group ( $>60$ years) disclosing their observations over 40 years regarding changing weather patterns, environment, and climate and thus their collective impacts on seasonal agricultural practices, water supply-demand infrastructure (mostly tanks), and water requirements of diverse communities. It was illustrated that communities settled in slums, professional communities of farmers, fisherfolks, and livestock managers, and communities from socially marginalized and poor economic backgrounds witnessed comparatively greater impacts of climate change in terms of higher unmet domestic and sectoralspecific (such as agricultural) water demand. As a result, young generations were found mostly disinterested to continue farming professions, instead, migrated from rural to urban areas for sub-optimal livelihood opportunities. At the same time, residents in the vibrant urban catchments who switched to groundwater pumping in order to ensure continuous domestic water supply faced declining groundwater potential threats. Issues complicated further due to drought conditions occurring during monsoonal seasons and floods during the non-monsoonal seasons. Past researches have validated the interviewee's experience regarding the recurrent phenomena of alternate flood and drought events and their severe impacts on water supply-demand aspects in Madurai (Surendran et al., 2017; Tauhid and Zawani, 2018; Avashia and Garg, 2020). In general, the local communities and tank users were found informed about short-term weather changes and the long-term influence of climate change on their water resources systems. Determining the local strategies being adopted by the affected communities in response to the changing weather, environment, and climate can provide vital inputs for policymakers, local administrators, and governing agencies to improving existing water supply-demand frameworks across VTCS.

\section{Analyzing Seasonal Rainfall Fluctuations and Their Impacts on Madurai City}

Based on the statistical analysis, Madurai city receives a normal annual rainfall of the magnitude $930.25 \mathrm{~mm}$. Of this, $\sim 45 \%$ of the rainfall is received during the N-E monsoon, while $\sim 36 \%$ is received during the S-W monsoon. Figure 2 shows the comparative analysis of normal seasonal rainfall with actual seasonal rainfall (2002-2018). Results for the principal rainfall season viz., N-E monsoon indicated that of the 17 years, percentage departure was recorded negative for 12 years, ranging between -1 and $-63 \%$. In the case of the $\mathrm{S}-\mathrm{W}$ monsoon, the percentage departure was recorded negative for 13 years, ranging between -18 and $-66 \%$. Overall, the seasonal monsoon rainfall in Madurai city was observed highly erratic with a higher deficiency in magnitude as compared to the normal rainfall. Furthermore, rainfall during the winter season recorded a negative percentage departure in the range of -3 to $-99 \%$ for 13 years, while the summer season was recorded in the range of -4 to $-117 \%$ for 10 years. The higher negative magnitudes of percentage departure across all seasons showcased inconsistency of rainfall pattern in Madurai city. Though tanks were constructed given the understanding that rainwater harvesting could be facilitated during monsoon seasons followed by its diverse applications during non-monsoon seasons, low monsoonal rainfall magnitudes with higher fluctuations can drastically impact overall tank functionality, thereby tank irrigation and agricultural practices.

Events of flash floods and long spells of droughts have increased drastically across the Madurai district. Tauhid and Zawani (2018) elucidated that the unsustainable expansion of the Madurai city in terms of human settlement caused through floodplains or by encroaching on traditional water bodies such as tank catchment or water spread area. Urban developmentinduced land-use transformations coupled with climate changerelated rainfall variation increased the risk for urban flooding. Avashia and Garg (2020) further added that in response to rapid and rising urbanization, flooding in cities such as Madurai drastically increased from $0.3 \%$ in 1991 to $16 \%$ in 2015 . The rising flood events were primarily derived from an increase in builtup cover by $\sim 21 \%$ and a decline in open and green spaces by 3.7 and $5.8 \%$, respectively. Besides this, yet in other studies on recurrent droughts, Surendran et al. (2017) demonstrated that the Madurai region witnessed 20 years of drought in the last 100 years, wherein the drought events remained cyclic occurring almost every 3-7 years. Furthermore, their study identified seven events of droughts since the 1970s, thereby signifying the need for devising strategic preparedness plans to combat droughts. Altogether, the current study findings on prevailing rainfall pattern in Madurai city along with supporting research findings alarms to reconsider the potential of rainfed-based water sources 

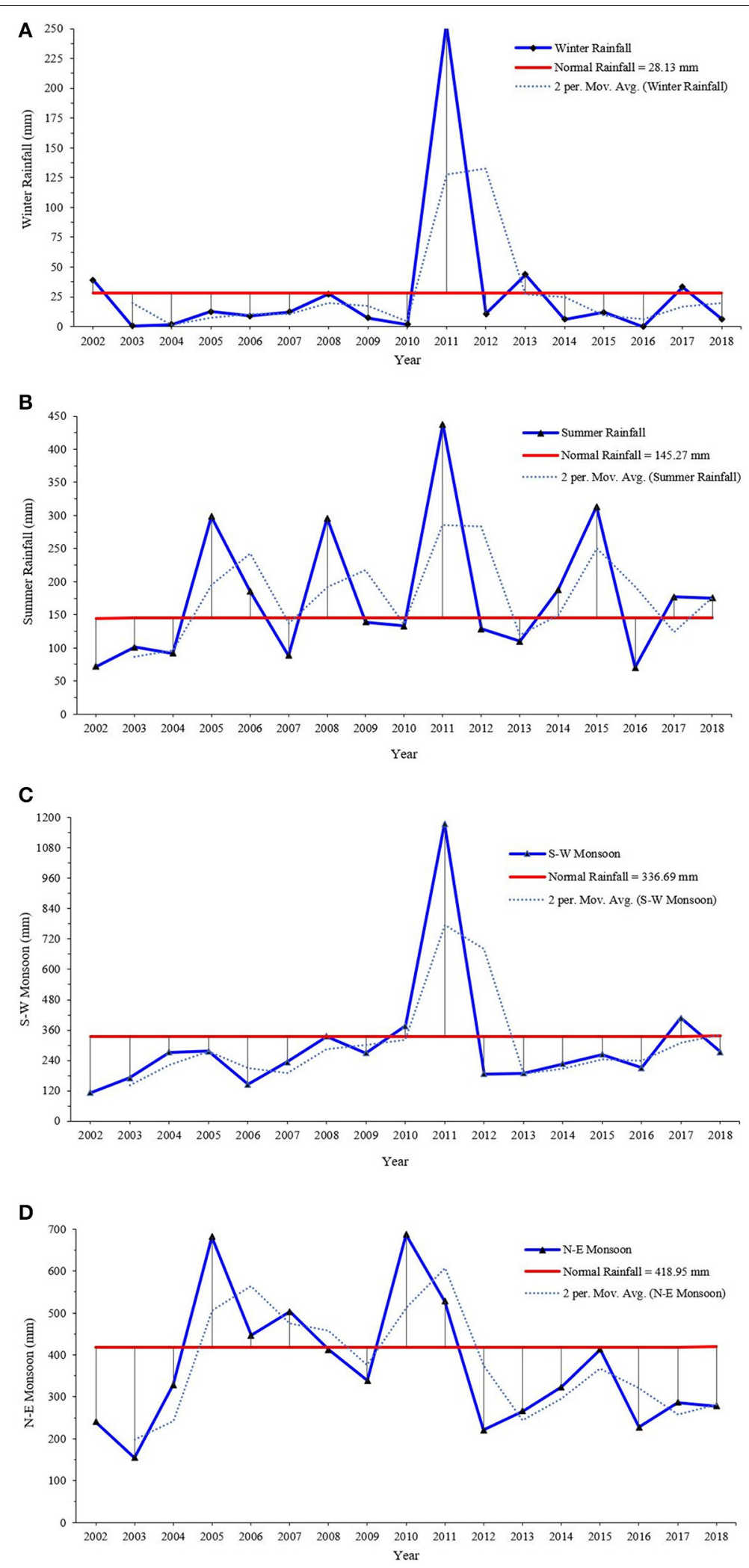

FIGURE 2 | Seasonal rainfall analysis of Madurai city: (A) Winter, (B) Summer, (C) South-West (S-W) Monsoon, and (D) North-East (N-E) Monsoon. 
such as Vaigai dams, Periyar dams (both dams are drinking water sources for Madurai city), and tanks under VTCS (the primary source for agriculture). Therefore, the aforementioned climate change implications called for a detailed field investigation for quantifying actual water supply and demand for satisfying domestic and agricultural needs across VTCS in Madurai city.

\section{Analyzing Domestic Water Supply-Demand Framework}

Table 1 provides data on region-wise population distribution and projected population for 2019. It could be inferred that $70 \%$ of the total population was concentrated in urban catchments ( $C 5$ and C6) followed by $22 \%$ in the peri-urban ( $C 3$ and $C 4)$, while the remaining population was located in rural catchments $(\mathrm{Cl}$ and $C 2$ ). The field investigation and household survey revealed that the municipal water supply was limited to urban and peri-urban catchments while rural catchments were dependent on wells (dug wells and borewells) for domestic water requirements. The PRA study emphasized that the villagers were not facing the issues in meeting their domestic water demand despite no municipal water supply. Due to this, the present study didn't consider estimating unmet domestic water demand in rural areas. On the other hand, higher density in urbanized catchments caused higher water demand thereby higher stress for meeting domestic water demand. Results of unmet domestic water demand for each catchment based on the population for the given seasons are shown in Figure 3. The results indicated that the unmet domestic water demand was highest during the summer ( $75 \%$ in peri-urban and $70 \%$ in urban) followed by winter $(25 \%$ in periurban and $41 \%$ in urban). On the contrary, the N-E monsoon received the full municipal water supply (meeting $100 \%$ domestic water demand) while the S-W monsoon received about $90 \%$ of domestic water demand via municipal supply. The basic source of domestic water to the Madurai city was received from the Vaigai dam which, in turn, received supply from the Periyar dam. As the Periyar dam is rain-dependent and given the erratic rainfall pattern in the Madurai region (Viswanath et al., 2020), the entire process of water supply in the Madurai city was observed inconsistent around the year. The aforementioned findings have also been showcased in various other studies and media reports (Ramesh, 2018; India.com, 2019; Times of India (ToI), 2019).

\section{Analyzing Agricultural Water Supply-Demand Framework}

Agriculture practices across VTCS were observed limited to three catchments viz., C1, C2 (entire rural catchments), and C6 (only urban catchment) while in the remaining catchments, agricultural land was observed abandoned either due to the lack of the potential irrigation water source (such as tanks) or due to the issues of encroachments as a consequence of the rapid expansion of the city (Tamilenthi et al., 2015). The major Kharif crop cultivated in these catchments was paddy while even during Rabi season, the paddy was the first option considered by the farmers for cropping. In general, farming communities were observed to prefer two cropping seasons for paddy cultivation and in few cases up to three. However, a high percentage deficiency in rainfall, ranging between 10 and 50\% (Geetha et al., 2020) along with rapidly declining water levels from tanks and wells inside tank catchment were observed, disrupting the agricultural practices limiting it to one season. In addition, as the irrigation source for cropping was tank-fed (which itself was rain-dependent), the cropping season appeared limited to the S-W monsoon and N-E monsoon seasons (Figure 4). The unmet agricultural water demand in C6 during the S-W monsoon was estimated at 95\% that subsequently reduced to $90 \%$ during the N-E monsoon. A reason for such high unmet demand was the poor water availability from the T8 (Vandiyur tank). Several past studies on the agricultural patterns have highlighted irrigation water supply issues in Madurai city in line with the aforementioned findings (Indian Water Portal (IWP), 2015; Kannan, 2016; Business Standard (BS), 2019). On the other hand, the unmet water demand in $\mathrm{C} 1$ and $\mathrm{C} 2$ during both $\mathrm{S}-\mathrm{W}$ monsoon and N-E monsoon was 15 and $0 \%$, respectively. Despite no municipal water supply, the rural catchments continued to access both irrigations (using system tanks) and domestic water supply sources (using open wells and borewells) from their catchment area.

\section{Analyzing Groundwater Level Fluctuations}

Analysis of the depth to groundwater extraction was made in order to ascertain temporal and spatial disparity in groundwater availability in the VTCS region. The groundwater extraction levels for 2003, 2008, and 2018 are shown in Figure 5. Inference from the groundwater data and its further validation from the field survey indicated that from $2003, \sim 60 \%$ of the groundwater levels changed from safe (annual natural recharge above the annual extraction rate) to critical status (annual extraction above annual natural recharge), leading to unsustainable groundwater levels. The depth of tubewell and borewell to extract these groundwater resources was found to increase at an alarming rate from eight meters below groundwater level (bgl) on average in the year 1990 (findings from the household survey) to $60 \mathrm{~m} \mathrm{bgl}$ in 2007 (650\% increase) to further $200 \mathrm{~m}$ bgl in $2018(2,400 \%$ increase). This accounted for a drop in the groundwater level at the rate of $7 \mathrm{~m} \mathrm{bgl} /$ year. During the same timeline, the municipal water supply for domestic purposes became irregular which forced the residents to either purchase drinking water cans or shifts to more and deeper groundwater extraction using wells (Ramesh, 2018; India.com, 2019; Times of India (ToI), 2019).

The spatial analysis revealed the higher groundwater declining rates in the urban regions (wells located closer to the bank of the Vaigai river) followed by peri-urban (wells located at the central region of the cascade) with reference to the depth of extraction. Whereas, the least rates were recorded in the rural areas (uppermost region of the entire cascade). The average depth to extract groundwater was determined to be approximately $200 \mathrm{~m} \mathrm{bgl}$ in urban regions whereas the same for the peri-urban was $\sim 75 \mathrm{~m} \mathrm{bgl}$ and for the rural regions was $\sim 10 \mathrm{~m}$ bgl. As the irrigation practices remained prevalent in the rural catchments and the household surveys further confirmed regarding adequacy in their water availability, it was inferred that the active irrigation tanks were able to recharge groundwater resources, thus the wells, comparatively more than the urban and peri-urban tanks. Previous studies and media 
TABLE 1 | Estimation of population of each catchment in Madurai for the year 2019 (Benson et al., 2020).

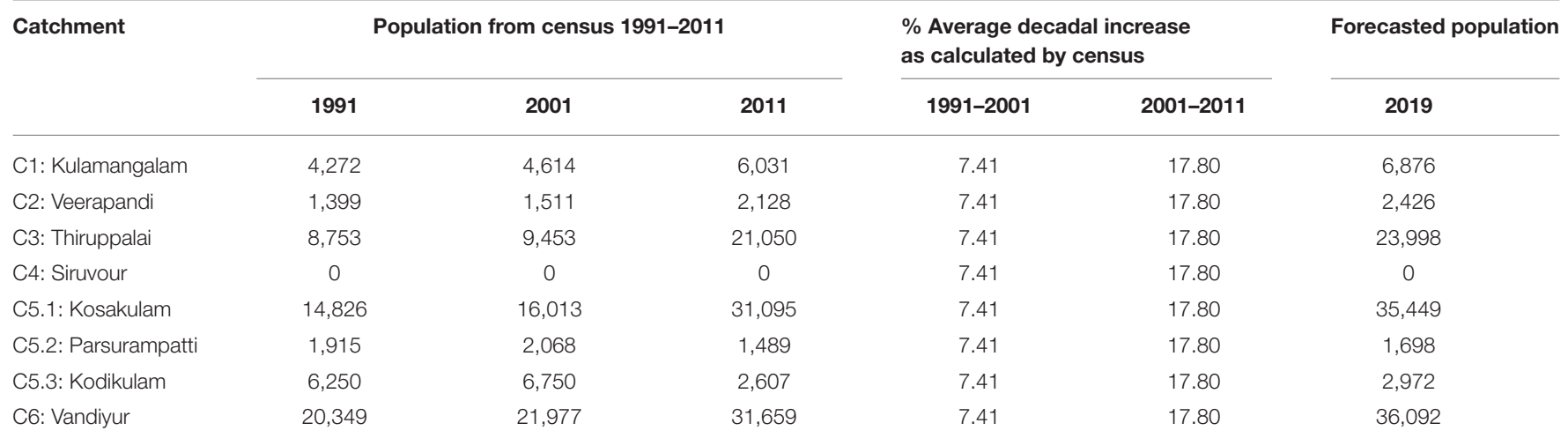

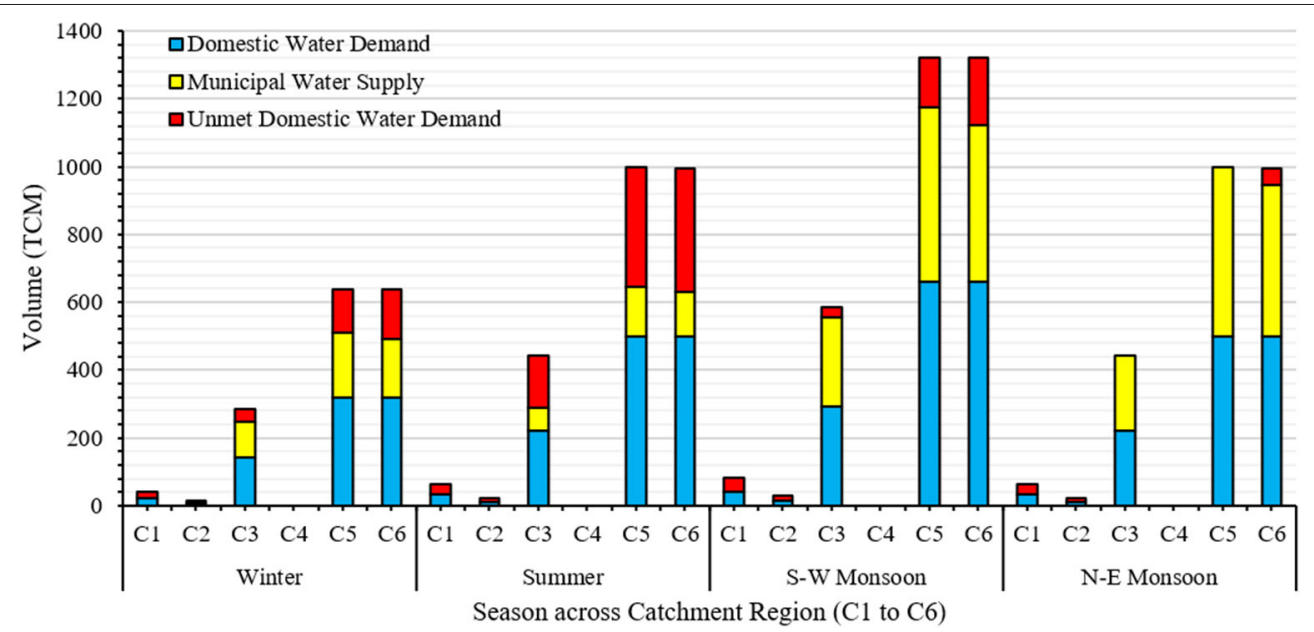

FIGURE 3 | Analysis of seasonal variation in domestic water requirements, municipal water supply, and unmet water demand across catchments (C1-C6) in Madurai city [C1: Kulamangalam; C2: Veerapandi; C3: Thiruppalai; C4: Siruvour; C5: Kosakulam- Parsurampatti- Kodikulam; C6: Vandiyur].

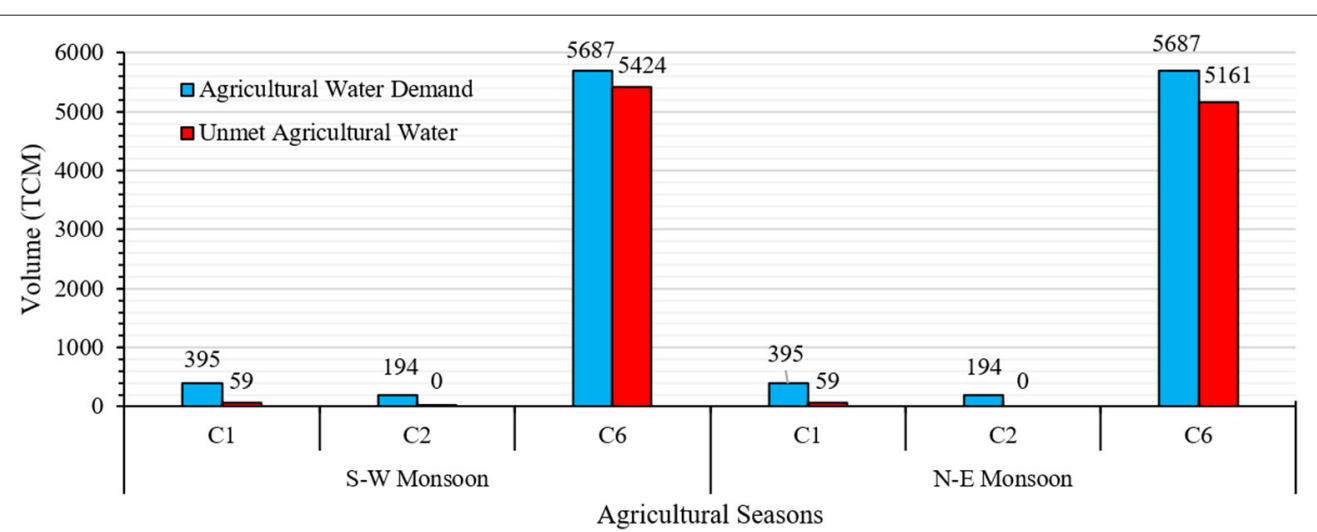

FIGURE 4 | Analysis of seasonal variation in agricultural water requirements (tank-fed based agricultural water supply) and corresponding unmet water demand across seasons in Madurai city [C1: Kulamangalam; C2: Veerapandi; C6: Vandiyur].

reports on depleting and exploiting groundwater resources in Madurai city also reasonably demonstrated the aforementioned findings (Kannan, 2016; Madurai Corporation, 2020; National Water Mission (NWM), 2020).

\section{Analyzing Sedimentation of VTCS}

The rural tanks were observed being actively used for irrigation and livestock management purposes while as per field investigations and from Kannan (2016), the urban and 


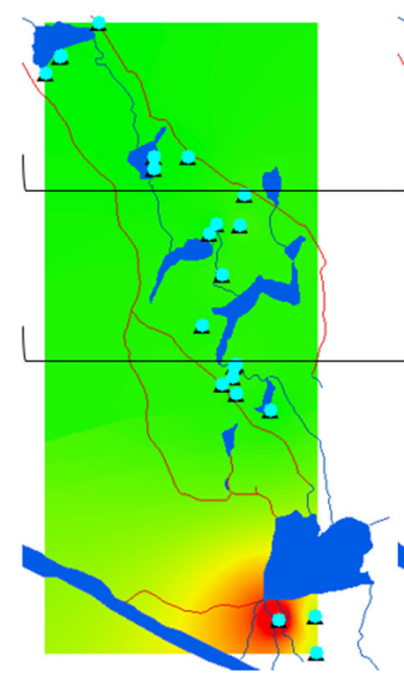

2003

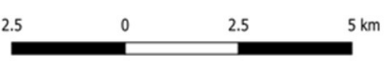

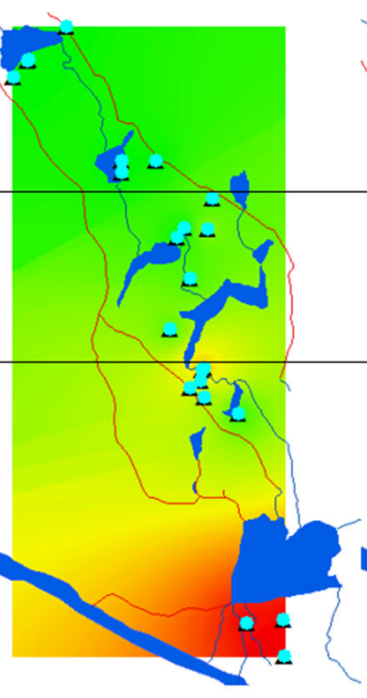

2008

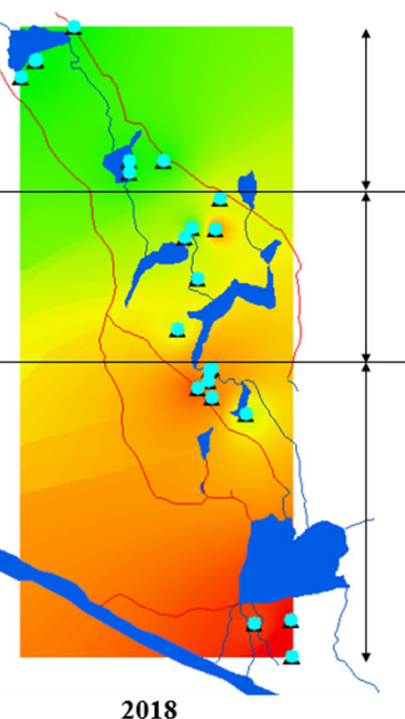

2018

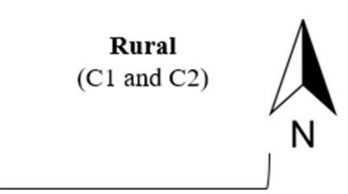

Peri-Urban

(C3 and C4)

Urban

(C5 and C6)

\section{Depth of Wells}

5-15 meters

15-100 meters

100-300 meters

Borewells

FIGURE 5 | Spatial analysis of fluctuation in-depth to groundwater extraction using wells (borewells and open wells) in Vandiyur tank cascade system (VTCS) of Madurai city [C1: Kulamangalam; C2: Veerapandi; C3: Thiruppalai; C4: Siruvour; C5: Kosakulam- Parsurampatti- Kodikulam; C6: Vandiyur].

peri-urban tanks were observed mostly unused due to their encroached tank catchment and reduced command area. As a result, these tanks, instead of functioning as irrigation tanks, were observed as a source for groundwater percolation and influencing micro-climatic conditions. However, the rate of groundwater recharge is directly linked to the maintenance facets of the tanks. For instance, the sedimented tanks may allow lower to zero groundwater recharge while desilted and maintained tanks may lead to higher groundwater recharge (Reddy et al., 2018). Considering this, field surveys were made inside the tank catchment and spread area in order to ascertain the volume of silt deposited. This would allow assessing tank performance given spatio-temporal components of groundwater recharge in the study area.

Findings from the site surveys of VTCS indicated that the volume of the tanks estimated was in the range of 30 to $70 \%$ of the actual volume of the tanks. While the remaining volume was occupied by the silt deposited from the upstream tanks. From Figure 6, it can be inferred that the urban and periurban tanks were more silted than rural tanks. In general, sedimentation decreased the storage potential of the VTCS from 30 to $70 \%$ between 2002 and 2019. As a result, even though VTCS's original storage potential could satisfy the water demands of the catchment area, with high sedimentation there was a reduced water storage scenario, which led to the ongoing water supply stress in the region. Similar results have been showcased in several pieces of recent studies including media reports on the issues regarding sedimentation of the Madurai tanks due to ignorance in maintenance (Kannan, 2016; The Hindu (TH), 2019b; Development of Human Action (DHAN), 2020).

\section{Analyzing Surface Water Level Fluctuations in VTCS}

The field investigations revealed that the average percentage of water availability was maximum during the N-E monsoon ranging from 20 to $50 \%$ of the total volume of the tank, followed by winter, in the range of $10-30 \%$. There was no water available during summer, however, sewage discharge from underground pipelines released from the local households contributed to the volume in T4, T5, and T8 (all tanks in urbanized catchments), as shown in Figure 7. Therefore, the water availability in these tanks was mostly unavailable during summer. Even during the S$\mathrm{W}$ monsoon, the average percentage of water availability in tanks was recorded in the range of null to $30 \%$. One of the reasons, as discussed previously, for this anomaly was the erratic rainfall pattern (Glendenning et al., 2012) during the S-W monsoon. While in the case of winter, it was due to the N-E monsoon that the water availability in the tanks sustained till March and continued to meet agricultural water demand. The findings on higher seasonal variation in the water level across Madurai tanks have also been indicated in several past studies (Kannan, 2016; Ramesh, 2018; Development of Human Action (DHAN), 2020).

\section{DISCUSSIONS}

\section{Analysis of Agricultural Water Demand-Supply Under Rehabilitated VTCS Scenarios}

Before discussing the suitable site-specific agricultural water demand management strategies, which would mostly be addressed through revitalizing VTCS, quantifying the degree 


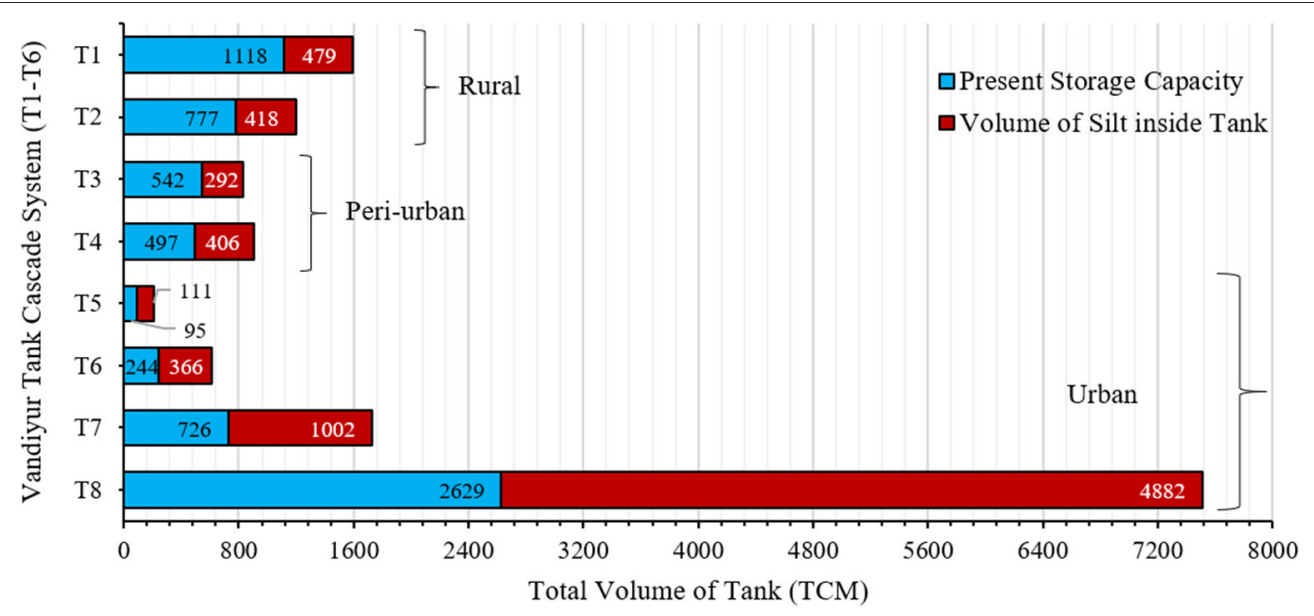

FIGURE 6 | Categorization of the total volume of the tank $(T)$ into the volume of silt and volume of the present storage capacity of Vandiyur tank cascade system (VTCS) in Madurai City [T1: Kulamangalam; T2: Veerapandi; T3: Thiruppalai; T4: Siruvour; T567: Kosakulam- Parsurampatti- Kodikulam; T8: Vandiyur].

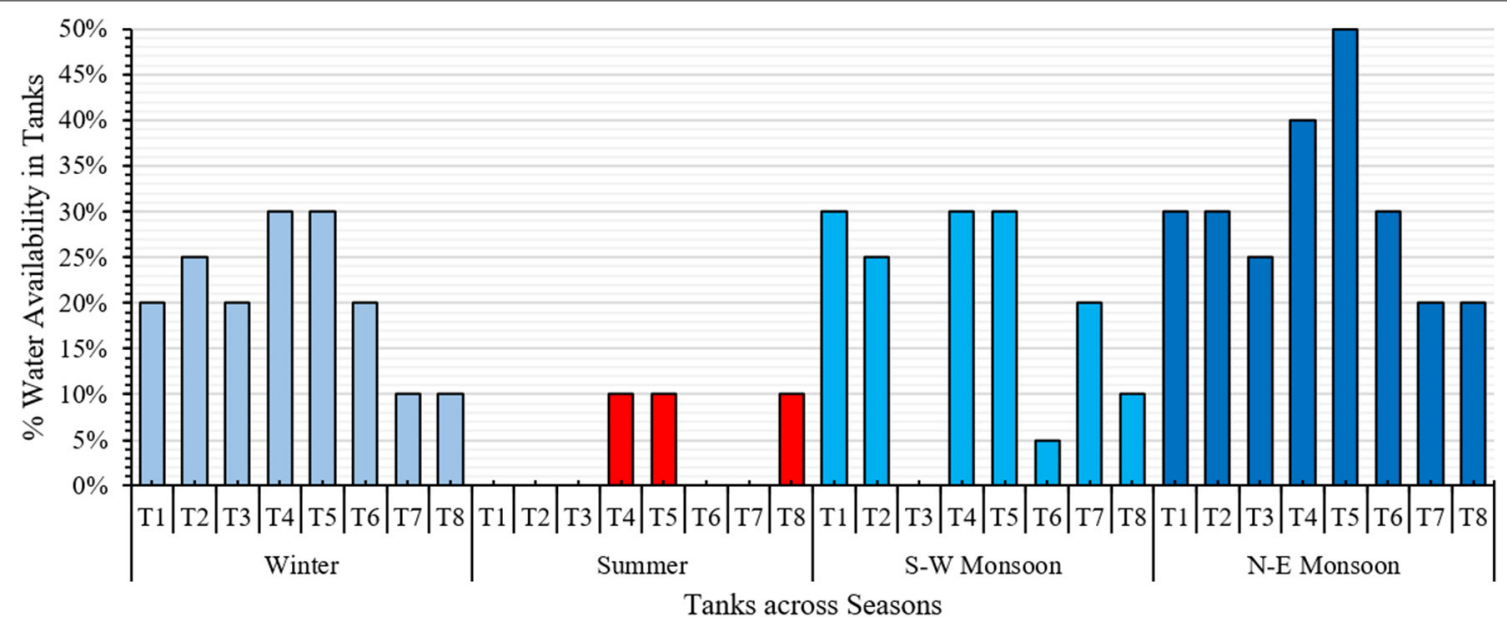

FIGURE 7 | Seasonal variation in the percentage water availability of tanks (T1-T8) in Vandiyur tank cascade system (VTCS) of Madurai City (It is the sewage which is observed during summer and highlighted in red) [T1: Kulamangalam; T2: Veerapandi; T3: Thiruppalai; T4: Siruvour; T567: Kosakulam- Parsurampatti- Kodikulam; T8: Vandiyur].

to which rehabilitation of the tanks would indeed satisfy demand was paramount. Therefore, the present study developed rehabilitation scenarios based on the spatio-temporal variations in water availability across VTCS. It was considered from the grounded field investigation and qualitative surveys that a tank under VTCS might attain efficiency, as high as 60\% during summer, $70 \%$ during winter, $80 \%$ during S-W monsoon, and $90 \%$ during N-E monsoon season. The percentage efficiency was subjected to the consideration that the rainfall will occur adequately (zero percentage departure) across each of the tank's catchment areas. In addition, the efficiency of the tank was assumed highly correlated with their storage potential. For example, a $90 \%$ efficient tank reflected $90 \%$ storage potential of an individual tank of VTCS in the N-E monsoon season. This exercise was conducted in order to understand how significantly a rehabilitated tank can satisfy unmet agricultural water demand against currently prevailing tank conditions. Broadly, such exercises can sensitize the local administration and policymakers to strengthen their attempts toward revival, rehabilitation, and restoration of the tank's functionality.

Figure 8 indicated the season-wise impact of tank rehabilitated scenarios on the existing correlation between agricultural water demand and unmet agricultural water demand. Agricultural practices dominated during S-W monsoon and N-E monsoon seasons in C1, C2, and C6, wherein unmet water demand was observed significantly high. However, under rehabilitated tank irrigation status, water availability could be 224,392 , and $6 \%$ more than the agricultural water demand during S-W monsoon, and 264, 433, and 19\% more during N-E monsoon in C1, C2, and C6 catchments, respectively. These results evidently directed that the rehabilitation of the tanks in active regions can address high unmet water demand issues. 


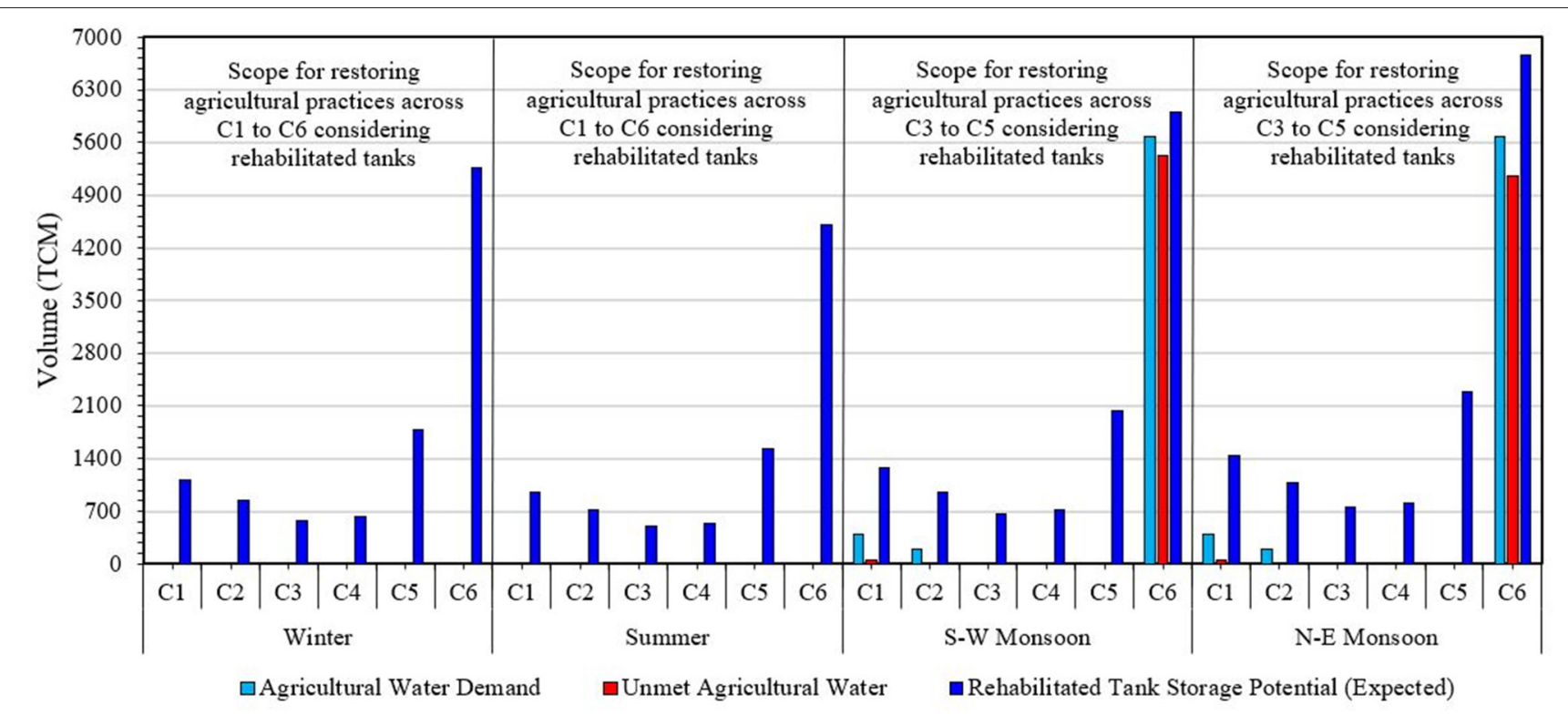

FIGURE 8 | Linkages between agricultural water demand, unmet agricultural water demand, and rehabilitated tank storage potential in VTCS at Madurai city [C1: Kulamangalam; C2: Veerapandi; C3: Thiruppalai; C4: Siruvour; C5: Kosakulam- Parsurampatti- Kodikulam; C6: Vandiyur].

Whereas, the likelihood of restoring agricultural practices in the catchments $C 3, C 4$, and $C 5$, under rehabilitated tank irrigation scenarios was observed achievable given the restored potential of tank storage for command-level irrigation. Even though the agricultural practices were observed impeded during the winter and summer seasons, the restored tank irrigation and storage potential can altogether generate scopes for advancing agricultural practices even during water-scarce seasons. This is attainable as a result of the restored tank storage and ensuring its availability even during critical seasons such as summer. As discussed, the latter can be manageable provided sustainable tank revitalization measures can be adopted.

\section{Climate-Resilient Measures for Water Supply-Demand Management}

The appropriate measures for each catchment were prioritized given the findings from field surveys, PRA, and recommendations proposed by active NGOs, WUAs, PWD, and local government authorities. Revival, restoration, and rehabilitation measures for VTCS were the most pressing recommendation proposed in the context of redefining the purpose of the lake as per the future vision of the local communities through multiple stakeholder convergences. This majorly included structural developments of tanks under VTCS, such as provisioning dead storage in tanks to create water storage during non-monsoon seasons, provisioning sedimentation tanks to keep a check over the intrusion of silt transported from upstream catchments, and bringing adequate, unrestricted, and safe water to the tank by synchronizing existing VTCS and Periyar main canal system. In fact, past studies have substantially demonstrated that the micro (or meso)-scale water harvesting techniques using small surface storage structures can positively increase hydro-environmental impact (Geekiyanage and Pushpakumara, 2013; Agoramoorthy et al., 2016; Reddy et al.,
2018). Hence, this study found desiltation of the tanks along with judicious surface water - groundwater utilization, especially located in the peri-urban and urban catchments, as a "need of the time" recommendation for improving the groundwater percolation scenarios. Additionally, transdisciplinary approaches and community participation are recommended given achieving sustainable water resources management and judicious water supply-demand framework during critical water-scarce seasons, as reasonably adopted by Maheshwari et al. (2014), Liehr et al. (2017), and Pradhan et al. (2018). These approaches can improve groundwater levels, thereby water supply for domestic and agricultural purposes even during critical water-scarce seasons. Although groundwater levels were observed reasonable for irrigation in the rural catchments, the present study findings advocated for monitoring increasing command level dug wells to evade future groundwater implications. The aforesaid provisions were required primarily across all catchments and have been discussed in considerable depth in recent studies and media reports (Indian Water Portal (IWP), 2015; Kannan, 2016; Reddy et al., 2018; The Hindu (TH), 2019a; Development of Human Action (DHAN), 2020; Srivastava and Chinnasamy, 2021a,b). Based on the results and discussion, suitable catchment-specific tank development measures for minimizing unmet irrigation and domestic water demand were proposed, as listed in Table 2. Furthermore, it is envisaged that climate change can add to the ongoing stressors for sustainable water management in the region. For example, as demonstrated in the results, rainfall patterns in Madurai city were dramatically altered given their percentage departure from the normal rainfall in the study period. Many studies have shown (for example, Dhanya and Ramachandran, 2016; ADB, 2020; Khadke and Pattnaik, 2021) that, due to climate change, there will be frequent climate extremes, including floods and droughts. Under such scenarios, a rehabilitated tank cascade system, as shown above, can aid in 
TABLE 2 | Proposed recommendations for VTCS development for ensuring water supply-demand across rural, peri-urban, and urban catchments.

Existing practice/policy Impacts and implications

There are no acts or legal provisions dedicated to preserving the tank cascade system

Different Government department works independently to resolve encroachment issues; coordination among them is limited

Scientific attempts to enumerate the tank population and their conditions by Government is limited

Implementation of rainwater harvesting schemes using farm ponds and community wells are inadequate in tank command areas

Coordination between State Government and Village-level Panchayat for implementing Central Government schemes such as Prime Minister's Village Development Schemes, etc. is limited

Not enough emphasis laid on educating the masses (tank stakeholders) on the conservation of common-pool resources through participatory approaches

No documentation or guidelines on tank-fed-based agriculture is laid and made available in the public domain for tank user communities

Apart from erratic rainfall pattern, over tank irrigation during plentiful tank storage by farmers, resorting to wastage of water, results in water scarceness for the second crop season

Participatory engagement in tank development to ensure groundwater recharge (for borewells and dug wells) and efficient tank irrigation is needed to be strengthened; policies on such attributes hardly provide specific guidelines on people's contributions to the implementation of the tank rehabilitation programs

Roof-top rainwater harvesting needed to be provisioned in the peri-urban and urban context on a mandatory basis to existing and upcoming settlements

Research and academic institutions are not paying sufficient attention to acknowledge the contribution of tanks in water supply and demand characteristics and thus the conservation efforts are futile given the lack of holistic and scientific approaches
Tank rehabilitation, restoration, and revival initiatives under "Tank Preservation Act" required to be drafted; separate policies under the head "Tank Development and Management" required to be drafted along with its constitutional recognition

Common guidelines to be framed in consultation with tank' stakeholders; widespread publicity for the same should be done via Tank and Water User Associations

Policy needs to be drafted for developing and documenting high-resolution satellite imageries to enumerate tanks and their conditions

Local Government should facilitate and encourage the formation of farm ponds and community wells inside the tank command area by provisioning bank loans to farmers

State Government should implement village development schemes ensuring proper coordination with local Panchayat in line with National Water Policy

Print, visual-based, and social media should be employed to sensitize the masses; Non-Government Organizations (NGOs) should be encouraged to educate rural masses

Identification of best practices under the tank-fed-based agricultural system is required to be drafted in consultation with tank-fed farmers and to be made available as a user manual to the concerned tank communities

Poor irrigation practices such as night irrigation, tank irrigation within 4 days of rainfall, leakages, and wastage due to mismanagement and inequitable water distribution needed to be documented and should be made available to the farmers under "Don't" for tank-fed agricultural practices

Specific policies on people's inclusion in the implementation process are required to be drafted; reconsideration to people-centered participatory approach along with indigenous techniques of water supply-demand management needed in the rehabilitation programs

Policies focusing on designs of roof-top rainwater harvesting tanks along with stringent policies on their inclusion for meeting domestic water demand, maintenance by the households, and utilization needed to be specified

Institutions of national importance should consider tanks in their research domain; should conduct evidence-based research on improving water supply and demand provisions using tanks and their inclusion in the modern water supply system
Dedicated acts preserving tank functionality can sustain environmental services provided by tanks such as surface-groundwater interaction resulting in groundwater percolation, natural hazard mitigation, irrigational needs for agricultural practices, and tank ecosystem and biodiversity conservation

Periodical monitoring along with increased social bondage can ensure prevention and check over illegal encroachments; tank storage potential can be maintained, thereby water demands

Periodic monitoring of tank's conditions through satellite imageries followed by ground-truthing can provide evidence for site-specific tank rehabilitation designs

Farm ponds and community wells have the potential to supplement tank water storage and monsoonal rainfall; formation of such structures can altogether strengthen public-participatory approaches toward tank development

Such coordination can result in establishing groundwater recharge structures and improving tank capacities which altogether can increase water storage, thereby improved water supply-demand management

Lack of awareness resulted in encroachments, degradation of tank ecosystem, and degeneration of tank irrigation functionality across VTCS; awareness of these attributes through hand-on experience can increase dependability on tanks

Descriptive understanding of site-specific initiatives on crop diversification, alternate cropping techniques, enhancement of crop yield under low water conditions, and selection of appropriate crops under the feasibility of tank irrigation can help improve crop productivity even under limited tank water supply

Conservation efforts for saving water by introducing recent techniques to the tank-fed farmers can provide adequate water availability for the second and even third cropping season; appropriate attempts can sustain agricultural practices even during summer or low rainfall scenarios

Restoring tank institutions can enhance the protection of tank, thereby maintenance and management through decentralized community-level participation and governance; altogether these participatory-based conservation efforts can influence the tank ecosystem, water supply-demand facets, and hydro-ecological stability

Rainwater harvesting by individual households have the potential to meet most of the domestic water requirements apart from provisioning of groundwater percolation simultaneously with harvesting monsoonal rain

Research findings on tank water supply and demand can enumerate best management practices before replacing time-tested technology linked with the tanks; studies can allow differentiating between functional and non-functional tanks, thereby ascertaining better surface and groundwater consumption 
reducing vulnerabilities to such extremes by reducing the peak flood discharge during rainy events, and can also act as a buffer for water during drought times. However, making direct linkages between climate change indices would need further analysis on climate change parameters, which was beyond the current paper's focus. Developing an understanding of long-term climate and weather fluctuations, therefore, becomes imperative while designing policies for water allocation and equitable distribution.

\section{Future Directions}

Based on the following limitations, the present research urges future studies to conduct investigations in coherence with the present study objectives to further strengthen the findings on functionalities of VTCS, as described hereunder:

- The present study focused on estimating water supply parameters such as household water supply from municipal taps, tank-based irrigation water supply to the command areas, and spatio-temporal potential of tank storage capacity through site surveys and field experimentations. Nevertheless, there is always uncertainly, arising from inadequate data capture networks and measurement errors. In addition, the present study lacked access to a quality-controlled secondary information database and therefore developed field-based methodologies to foster supply-demand data collection. As uncertainty and error analysis is an important part of water balance estimation, this study urges future investigations to improve methodologies to reduce uncertainty errors in measurement data, which can be used to reduce uncertainty errors in the water supply-demand estimation.

- The findings of the present study were limited to agricultural and domestic water supply-demand, given the potential of the VTCS in two areas of each rural, peri-urban, and urban developmental setting across Madurai city. However, considering the Madurai district as a whole, there are, in total, 11 blocks comprising 665 revenue villages, wherein over 32,000 Micro, Small, and Medium Enterprises (MSME) exist as industrial units (https://madurai.nic.in/ industries-commerce/). Under these circumstances, apart from agricultural and domestic water demand, determining industrial water demand becomes an indispensable parameter to be considered while developing water supply-demand scenarios under limited water supply conditions. Future studies should expand the study boundary in coherence with the present research questions, thereby focus on industrial water requirements given the water supply potential of tanks and dams via irrigation department and municipal corporation.

\section{CONCLUSIONS}

The tank cascade system is integral to agricultural livelihood particularly in rural areas and mostly groundwater percolation sources in urban areas. Though the usage of tanks differed from region to region, they were commonly observed serving for drinking, protective irrigation, and natural hazard mitigation purposes. The present research attempted to understand the degradation of the Vandiyur tank cascade system (VTCS) and its impact on surface and groundwater resources in the context of managing water supply-demand frameworks. The study critically assessed the water supply-demand in rural, peri-urban, and urban catchments of VTCS and proposed a novel method to mitigate the impending crisis that is likely to accentuate with deteriorating climate change conditions. The study found overreliance of the local residents on municipal water supply and borewell/tubewell-based water supply sources. This consequently caused vulnerability toward water security given overexploitation of groundwater resources by $60 \%$ against its replenishment. As far as tanks were concerned, their functionality, from being irrigation supply sources, changed into percolation tanks due to encroachment of tank catchment and command area. Due to ignorance toward these traditional tanks, they remained mostly unmaintained and undergone siltation across time. The reduced storage potential of the tanks of VTCS, in the range of $30-70 \%$ and coupled with inconsistent municipal water supply, further stressed water issues resulting in higher unmet (deficit) domestic and agricultural water demand. The study concluded that in the context of increasing water demand but decreasing groundwater resources, the VTCS regions, specifically urbanizing catchments, were likely to face chronic water shortages coupled with recurrent floods in the foreseeable future.

A serious lack of community engagement was observed, more specifically in the urban context, when it comes to water supply and management. Instead of making decisions and plans for water security based on what the community demands, it was recommended to develop an understanding of the prevailing water issues followed by community engagement in order to design appropriate and catchment-specific water security plans. Therefore, community-level mobilization on sensitizing issues and their primary causes were strongly recommended. In summary, the study found an imbalance between the water draft and water availability for the water supply in peri-urban and urban catchments, while the rural catchments performed better in both tank performance as well as water availability for domestic purposes, despite no municipal water supply. However, all catchments witnessed the impacts of poor water availability during the summer causing residents to either purchase water or fetch water from distant sources. The overall assessment revealed that water management plans in the context of water security were much needed across the study site.

Finally, given the inevitable implications of climate change, the study concluded that the increasing agricultural water demand and declining agricultural practices were primarily driven by deteriorating VTCS. Additionally, over-abstraction of groundwater resources due to increasing settlements across VTCS, particularly in the urban landscape threatened the domestic water demand. Rain-dependent municipal water supply sources, such as the Vaigai dam, caused high unreliability in meeting adequate domestic water needs among urban settlements. Though public-participatory approaches in water supply-demand management, considering both supply-side and demand-side in the study area, were found limited, the study argued that the traditional tanks, if adequately managed, could provide sustainable water supply solutions, 
both for meeting the water demand as well as mitigate natural disasters, such as floods. Considering the existing policy implications, the study concluded that a lack of comprehensive consideration toward integrating tanks (VTCS), canals (dams), and groundwater (borewells), rather than treating them as a substitute for one another, could challenge achieving longterm sustainability in water supply-side frameworks. At the same time, water demand-side management via improving water conservation measures at the user-end needed further mobilization, which can be attained by drafting stringent policies preventing undesirable water losses both in domestic and agricultural facets.

\section{DATA AVAILABILITY STATEMENT}

The original contributions presented in the study are included in the article/supplementary material, further inquiries can be directed to the corresponding author.

\section{AUTHOR CONTRIBUTIONS}

PC conceptualized the ideas for the paper and guided the analysis, while AS conducted the field investigation and analysis.

\section{REFERENCES}

ADB (2020). Asian Water Development Outlook 2020: Advancing Water Security Across Asia and the Pacific. Philippines: Asian Development Bank (ADB).

Agarwal, S., Patil, J. P., Goyal, V. C., and Singh, A. (2019). Assessment of water supply-demand using water evaluation and planning (WEAP) model for Ur river watershed, Madhya Pradesh, India. J. Institut. Eng. A 100, 21-32. doi: 10.1007/s40030-018-0329-0

Agoramoorthy, G., Chaudhary, S., Chinnasamy, P., and Hsu, M. J. (2016). Harvesting river water through small dams promote positive environmental impact. Environ. Monit. Assess. 188, 1-11. doi: 10.1007/s10661-016-5640-5

Alaguraja, P., Durairaju, S., Yuvaraj, D., Sekar, M., Muthuveerran, P., Manivel, M., et al. (2010). Land use and land cover mapping-Madurai district, Tamilnadu, India using remote sensing and GIS techniques. Int. J. Civil Struct. Eng. 1, 91-100. doi: 10.6088/ijcser.00202010008

Allen, R. G., Pereira, L. S., Raes, D., and Smith, M. (1998). Crop evapotranspiration-Guidelines for computing crop water requirements-FAO Irrigation and drainage paper 56. Food Agric. Organ. 300:D05109.

Avashia, V., and Garg, A. (2020). Implications of land use transitions and climate change on local flooding in urban areas: an assessment of 42 Indian cities. Land Use Policy 95:104571. doi: 10.1016/j.landusepol.2020.104571

Bal, P. K., Ramachandran, A., Geetha, R., Bhaskaran, B., Thirumurugan, P., Indumathi, J., et al. (2016). Climate change projections for Tamil Nadu, India: deriving high-resolution climate data by a downscaling approach using PRECIS. Theor. Appl. Climatol. 123, 523-535. doi: 10.1007/s00704-014-1367-9

Balasubramanian, R., and Selvaraj, K. N. (2003). Poverty, Private Property and Common Pool Resource Management: The Case of Irrigation Tanks in South India. Kathmandu: South Asian Network for Development and Environmental Economics (SANDEE).

Basu, M., DasGupta, R., Hashimoto, S., and Hoshino, S. (2020). A multiactor and bottom-up perspective on attaining rural water security: qualitative evidence from India. Environ. Dev. Sustain. 23, 1461-1484. doi: 10.1007/s10668-020-00631-2

Bebermeier, W., Meister, J., Withanachchi, C. R., Middelhaufe, I., and Schütt, B. (2017). Tank cascade systems as a sustainable measure of watershed management in South Asia. Water 9:231. doi: 10.3390/w9030231

\section{FUNDING}

Financial support for field survey received from the Centre for Technology Alternatives for Rural Areas (CTARA) of the Indian Institute of Technology (IIT) Bombay in association with Centre for Urban Water Resources (CURE) of the DHAN Foundation, Madurai, India.

\section{ACKNOWLEDGMENTS}

The authors thank the Centre for Technology Alternatives for Rural Areas (CTARA) of the Indian Institute of Technology Bombay and the Ministry of Rural Development (MoRD), Government of India, New Delhi, for providing a fellowship platform for this work to be conducted. Thanks are due to field guide Mr. Elamuhil (Water Resources Engineer), Mr. Lokesh Sinram (Environmentalist), Mr. N. Venkatesan (Program Manager-Human Resource), Mr. V. Venkatesan (Chief Executive Officer-Vayalagam), Mr. A. Gurunathan (Director - The DHAN Academy), and Mr. M. P. Vasimalai (Executive Director-DHAN) from DHAN Foundation, Madurai. The authors acknowledge the kind support received from all the participants, farmers, village people, Panchayats, and PWD officials of Madurai city.

Benson, D., Gain, A. K., and Giupponi, C. (2020). Moving beyond water centricity? Conceptualizing integrated water resources management for implementing sustainable development goals. Sustain. Sci. 15, 671-681. doi: 10.1007/s11625-019-00733-5

Bhattacharjee, S. P. (2019). Ground water conservation and management in North Eastern India: adopting traditional wisdom. J. Geol. Soc. India 93, 250-251. doi: 10.1007/s12594-019-1134-8

Bonfils, C. J., Santer, B. D., Fyfe, J. C., Marvel, K., Phillips, T. J., and Zimmerman, S. R. (2020). Human influence on joint changes in temperature, rainfall and continental aridity. Nat. Clim. Change 10, 726-731. doi: 10.1038/s41558-020-0 $821-1$

Boretti, A., and Rosa, L. (2019). Reassessing the projections of the world water development report. NPJ Clean Water 2, 1-6. doi: 10.1038/s41545-019-0 039-9

Business Standard (BS) (2019). Water crisis in Madurai affects crop cycles. Available online at: https://www.business-standard.com/article/news-ani/water-crisisin-madurai-affects-crop-cycles-119112101466_1.html (accessed December 10, 2020).

Census of India (2011). Population enumeration data. Office of the Registrar General and Census Commissioner, India Ministry of Home Affairs, Government of India. Available online at: http://www.censusindia.gov.in/ 2011census/population_enumeration.aspx (accessed December 10, 2020).

Central Ground Water Board (CGWB) (2007). Central groundwater board. District Groundwater Brochure, Madurai district. Ministry of Water Resources Central Ground Water Board South Eastern Coastal Region Chennai. Available online at: http://cgwb.gov.in/District_Profile/TamilNadu/Madurai. pdf (accessed December 10, 2020).

Central Ground Water Board (CGWB) (2008). A state Profile, Groundwater scenario in Tamilnadu. Available online at: http://cgwb.gov.in/gw_profiles/st_ TN.htm (accessed December 10, 2020).

Chambers, R. (1994). The origins and practice of participatory rural appraisal. World Dev. 22, 953-969. doi: 10.1016/0305-750X(94)90 $141-4$

Chinnasamy, P., and Hubbart, J. A. (2015). Stream and shallow groundwater nutrient concentrations in an Ozark forested riparian zone of the central USA. Environ. Earth Sci. 73, 6577-6590. doi: 10.1007/s12665-014-3880-7 
Chinnasamy, P., Maheshwari, B., and Prathapar, S. A. (2018). Adaptation of Standardised Precipitation Index for understanding watertable fluctuations and groundwater resilience in hard-rock areas of India. Environ. Earth Sci. 77, 1-16. doi: 10.1007/s12665-018-7734-6

Chinnasamy, P., Maske, A. B., Honap, V., Chaudhary, S., and Agoramoorthy, G. (2021). "Sustainable development of water resources in marginalised semi? arid regions of India: case study of Dahod in Gujarat, India," in Natural Resources Forum, Vol. 12 (Oxford, UK: Blackwell Publishing Ltd.), 1-20. doi: 10.1111/1477-8947.12217

Chinnasamy, P., and Parikh, A. (2020). Remote sensing-based assessment of Coastal Regulation Zones in India: a case study of Mumbai, India. Environ. Dev. Sustainabil. 225, 1-20. doi: 10.1007/s10668-020-00955-Z

Chinnasamy, P., and Prathapar, S. A. (2016). Methods to Investigate the Hydrology of the Himalayan Springs: A Review. International Water Management Institute, 43.

Chinnasamy, P., and Shrestha, S. R. (2019). Melamchi water supply project: potential to replenish Kathmandu's groundwater status for dry season access. Water Policy 21, 29-49. doi: 10.2166/wp.2019.080

Chintalapudi, P., Khadse, G., Pujari, P., Sanam, R., and Labhasetwar, P. (2017). Integrated water security plan for water scarcity villages in central India. Environ. Dev. Sustain. 19, 2547-2564. doi: 10.1007/s10668-016-9850-3

Creswell, J. W., and Clark, V. L. P. (2007). Designing and Conducting Mixed Methods Research. London: Sage Publication.

CWC (2019). Annual report - 2019-20. Department of Water Resources, River Development and Ganga, New Delhi, Central Water Commission, Government of India. Available online at: http://cwc.gov.in/sites/default/files/arcwc2019-20. pdf (accessed January 29, 2021).

Development of Human Action (DHAN) (2020). The project revival. Centre for Urban Water Resources, DHAN Foundation, Madurai. Available online at: https://www.dhan.org/dhancure/\#tf-home (accessed December 10, 2020).

Dhanya, P., and Ramachandran, A. (2016). Farmers' perceptions of climate change and the proposed agriculture adaptation strategies in a semi arid region of south India. J. Integr. Environ. Sci. 13, 1-18. doi: 10.1080/1943815X.2015.10 62031

District Profile (2016). Madurai district. Office of the Deputy Director of Statistics, Madurai, Tamil Nadu, India. Available online at: https://cdn.s3waas.gov. in/s3f5f8590cd58a54e94377e6ae2eded4d9/uploads/2018/06/2018062751.pdf (accessed January 26, 2020).

Erfani, T., Pachos, K., and Harou, J. J. (2018). Real-options water supply planning: multistage scenario trees for adaptive and flexible capacity expansion under probabilistic climate change uncertainty. Water Resour. Res. 54, 5069-5087. doi: 10.1029/2017WR021803

FAO (2009) "How to feed the world in 2050," in Proceedings of the Expert Meeting on How to Feed the World in 2050. Rome: FAO Headquarters, 24-26.

Geekiyanage, N., and Pushpakumara, D. K. N. G. (2013). Ecology of ancient tank cascade systems in island Sri Lanka. J. Marine Island Cult. 2, 93-101. doi: 10.1016/j.imic.2013.11.001

Geetha, I. R., Vidhyavathi, A., and Rani, S. P. (2020). Dynamics of land use pattern in Madurai district of Tamil Nadu in nexus with common property land resources. Curr. J. Appl. Sci. Technol. 39, 30-40. doi: $10.9734 /$ cjast/2020/v39i2030805

Glendenning, C. J., Van Ogtrop, F. F., Mishra, A. K., and Vervoort, R. W. (2012). Balancing watershed and local scale impacts of rain water harvesting in India a review. Agric. Water Manage. 107, 1-13. doi: 10.1016/j.agwat.2012.01.011

Godfray, H. C. J., and Garnett, T. (2014). Food security and sustainable intensification. Philos. Trans. R. Soc. B Biol. Sci. 369:20120273. doi: $10.1098 /$ rstb. 2012.0273

Government of India (GoI) (2002). Guidelines on Swajaldhara. Department of Drinking Water Supply, Ministry of Rural Development. Available online at: http://www.ielrc.org/content/e0212.pdf (accessed December 10, 2020).

Government of India (GoI) (2010). National rural drinking water programme: movement towards ensuring people's drinking water security in rural India. Department of Drinking Water Supply, Ministry of Rural Development. Available online at: https://jalshakti-ddws.gov.in/sites/default/files/ RuralDrinkingWater_2ndApril.pdf (accessed December 10, 2020).

Government of India (GoI) (2017). Towards drinking water security in India: lessons from the field. Department of Drinking Water and Sanitation, Ministry of Rural Development. Available online at: https://jalshaktiddws.gov.in/
sites/default/files/Towards\%20Drinking\%20Water\%20Security.pdf (accessed December 10, 2020)

Government of India (GoI) (2019). Guidelines for urban water conservation: Jal Shakti Abhiyan. Ministry of Housing and Urban Affairs, New Delhi, Government of India. Available online at: http://mohua.gov.in/upload/ whatsnew/5d1c7709d059eGuidelines_UWC_JSA03072019.pdf (accessed December 10, 2020).

Government of India (GoI) (2020). Jal adura mission. Department of Drinking Water and Sanitation, Ministry of Jal Shakti. Available online at: https:// jaljeevanmission.gov.in/content/about-jjm\#objectives (accessed December 10, 2020).

Greve, P., Kahil, T., Mochizuki, J., Schinko, T., Satoh, Y., Burek, P., et al. (2018). Global assessment of water challenges under uncertainty in water scarcity projections. Nat. Sustain. 1, 486-494. doi: 10.1038/s41893-018-0134-9

Habeeb, R., Gupta, Y., Chinwan, H., and Barker, E. (2019). Assessing demographic and water sensitivities arising due to urban water insecurity in Haldwani, Uttarakhand (India): a GIS-Based Spatial Analysis. J. Geovisualization Spatial Anal. 3:8. doi: 10.1007/s41651-019-0031-4

Hesse-Biber, S. N. (2010). Mixed Methods Research: Merging Theory With Practice. London: Guilford Press.

IFPRI (2012). Sustainable Food Security Under Land, Water, and Energy Stresses, in 2012 Global Hunger Index. Washington, DC: International Food Policy Research Institute (IFPRI).

India.com (2019). As Tamil Nadu Water Crisis Heightens, Govt-run Borewells Run Dry in Madurai. Available online at: https://www.india.com/news/india/astamil-nadu-water-crisis-heightens-govt-run-borewells-run-dry-in-madurai3710759/ (accessed December 10, 2020).

Indian Water Portal (IWP) (2015). Can Madurai's dying tanks be revived? Available online at: https://www.indiawaterportal.org/articles/dying-tanksmadurai-0 (accessed December 10, 2020).

IS 1172 (1993). (Reaffirmed 2007). Indian standard code of basic requirements for water supply, drainage and sanitation. Fourth Reprint, December 2010, UDC 628.1/.3: 006.76, Bureau of Indian Standards, New Delhi.

Kannan, K. T. (2016). Water Urbanism: Madurai, India. Columbia: GSAPP.

Khadke, L., and Pattnaik, S. (2021). Impact of initial conditions and cloud parameterization on the heavy rainfall event of Kerala (2018). Model. Earth Syst. Environ. 7:1-14. doi: 10.1007/s40808-020-01073-5

Kirono, D. G., Larson, S., Tjandraatmadja, G., Leitch, A., and Neumann, L., Maheepala, et al. (2014). Adapting to climate change through urban water management: a participatory case study in Indonesia. Reg. Environ. Change 14, 355-367. doi: 10.1007/s10113-013-0498-3

Komatsu, S., Yamamoto, Y., Ito, Y., Kaneko, S., and Dhital, R. P. (2019). Water for life: ceaseless routine efforts for collecting drinking water in remote mountainous villages of Nepal. Environ. Dev. Sustain. 22, 7909-7925. doi: 10.1007/s10668-019-00552-9

Kumar, N., Tischbein, B., Kusche, J., Laux, P., Beg, M. K., and Bogardi, J. J. (2017). Impact of climate change on water resources of upper Kharun catchment in Chhattisgarh, India. J. Hydrol. 13, 189-207. doi: 10.1016/j.ejrh.2017.07.008

Liehr, S., Röhrig, J., Mehring, M., and Kluge, T. (2017). How the social-ecological systems concept can guide transdisciplinary research and implementation: addressing water challenges in central northern Namibia. Sustainability 9:1109. doi: 10.3390/su9071109

Lindersson, S., Brandimarte, L., Mård, J., and Di Baldassarre, G. (2020). A review of freely accessible global datasets for the study of floods, droughts and their interactions with human societies. Wiley Interdiscip. Rev. 7:e1424. doi: $10.1002 /$ wat2.1424

Liu, J., Yang, H., Gosling, S. N., Kummu, M., Flörke, M., Pfister, S., et al. (2017). Water scarcity assessments in the past, present, and future. Earth's Future 5, 545-559. doi: 10.1002/2016EF000518

Madurai Corporation (2020). Natural resource profiling. Available online at: http:// www.maduraicorporation.co.in/natural-resources-profiling.html (accessed December 10, 2020).

Maheshwari, B., Varua, M., Ward, J., Packham, R., Chinnasamy, P., Dashora, Y., et al. (2014). The role of transdisciplinary approach and community participation in village scale groundwater management: Insights from Gujarat and Rajasthan, India. Water 6, 3386-3408. doi: 10.3390/w6113386

Mehran, A., AghaKouchak, A., Nakhjiri, N., Stewardson, M. J., and Peel, M. C., Phillips, et al. (2017). Compounding impacts of human-induced 
water stress and climate change on water availability. Sci. Rep. 7:6282. doi: 10.1038/s41598-017-06765-0

Merton, R. K. (1987). The focussed interview and focus groups: continuities and discontinuities. Public Opin. Q. 51, 550-566. doi: 10.1086/269057

Merton, R. K. (2008). Focused interview. Free Press, Simon and Schuster. Available online at: https://books.google.co.in/books?id=yLHwCMetDncC (accessed January 29, 2021).

Miller, K. A., and Belton, V. (2014). Water resource management and climate change adaptation: a holistic and multiple criteria perspectives. Mitigat. Adapt. Strat. Global Change 19, 289-308. doi: 10.1007/s11027-013-9537-0

MoJS (2019). Annual report - 2019-20. Department of Water Resources, River Development and Ganga, Ministry of Jal Shakti (MoJS), Government of India, New Delhi. Available online at: http://jalshakti-dowr.gov.in/sites/default/files/ AR_DoWR_RD_GR_2019-20_English.pdf (accessed January 29, 2021).

Molden, D., Murray-Rust, H., Sakthivadivel, R., and Makin, I. (2003). “A waterproductivity framework for understanding and action," in Water Productivity in Agriculture: Limits and Opportunities for Improvement, eds J. W. Kijne, R. Barker, and D. Molden (London: CAB Internaitonal), 1-18.

MoWR (2014). Guidelines for improving water use efficiency in irrigation, domestic, and industrial sectors. Ministry of Water Resources, Government of India, New Delhi. Available online at: http://www.mowr.gov.in/sites/default/files/ Guidelines_for_improving_water_use_efficiency_1.pdf. (accessed January 29, 2021).

NAPCC (2008). National action plan on climate change. Prime Minister's Council on Climate Change, Government of India, New Delhi. Available online at: http://nicra-icar.in/nicrarevised/images/Mission\%20Documents/NationalAction-Plan-on-Climate-Change.pdf. (accessed January 29, 2021).

National Water Mission (NWM) (2020). Chapter 4.1.19: Ground water resources Madurai district. Government of India. Available online at: http://nwm. gov.in/sites/default/files/Notes\%20on\%20Madurai\%20District.pdf (accessed December 10, 2020).

Nauges, C., and Strand, J. (2013). Water hauling and girls' school attendance: some new evidence from Ghana. Policy Research Working Paper, 6443. The World Bank, Washington DC, United States.

OECD (2012). The OECD Environmental Outlook to 2050: The Consequences of Inaction. The Hague: OECD and the PBL Netherlands Environmental Assessment Agency.

Palanisami, K. (2006). Sustainable management of tank irrigation systems in India. J. Dev. Sustain. Agric. 1, 34-40. doi: 10.11178/ jdsa.1.34

Parry, M., Evans, A., Rosegrant, M. W., and Wheeler, T. (2009). Climate Change and Hunger: Responding to the Challenge. Rome: World Food Programme.

Pradhan, A., Chan, C., Roul, P. K., Halbrendt, J., and Sipes, B. (2018). Potential of conservation agriculture (CA) for climate change adaptation and food security under rainfed uplands of India: a transdisciplinary approach. Agric. Syst. 163, 27-35. doi: 10.1016/j.agsy.2017.01.002

Ramesh, M. (2018). India's water crisis: lessons from Madurai, a city that adopted tanks and suffered after abandoning them. Available online at: https://www. firstpost.com/india/indias-water-crisis-lessons-from-madurai-a-city-thatadopted-tanks-and-suffered-after-abandoning-them-5011701.html (accessed December 10, 2020).

Reddy, V. R., Reddy, M. S., and Palanisami, K. (2018). Tank rehabilitation in India: review of experiences and strategies. Agric. Water Manage. 209, 32-43. doi: 10.1016/j.agwat.2018.07.013

SAPCC (2010). Summary of discussion national consultation workshop on preparation of state level strategy and action plan on climate change. Ministry of Environment, Forest and Climate Change, Government of India. Available online at: http://moef.gov.in/wp-content/uploads/2018/01/SAPCC-workshopsummary-2010.pdf (accessed January 29, 2021).

Saraswat, C., Kumar, P., Dasgupta, R., Avtar, R., and Bhalani, P. (2019). Sustainability assessment of the groundwater quality in the
Western India to achieve urban water security. Appl. Water Sci. 9:73. doi: 10.1007/s13201-019-0956-2

Srivastava, A., and Chinnasamy, P. (2021a). Water management using traditional tank cascade systems: a case study of semi-arid region of Southern India. SN Appl. Sci. 3:281. doi: 10.1007/s42452-021-04232-0

Srivastava, A., and Chinnasamy, P. (2021b). Investigating impact of land-use and land cover changes on hydro-ecological balance using GIS: insights from IIT Bombay, India. SN Appl. Sci. 3:343. doi: 10.1007/s42452-021-04328-7

Subramanya, K. (2013). Engineering Hydrology. New Delhi: Tata McGrawHill Education.

Surendran, U., Kumar, V., Ramasubramoniam, S., and Raja, P. (2017). Development of drought indices for semi-arid region using drought indices calculator (DrinC)-a case study from Madurai District, a semi-arid region in India. Water Resour. Manage. 31, 3593-3605. doi: 10.1007/s11269-017-1687-5

Tamilenthi, S., Arul, P., and Chandramohan, K. (2015). Detection of urban change and urban sprawl of Madurai city, Tamilnadu using GIS and RS. J. Environ. Protect. Sustain. Dev. 1, 107-120. Available online at: http://files.aiscience.org/ journal/article/html/70140022.html (accessed February 3, 2021).

Tauhid, F. A., and Zawani, H. (2018). Mitigating climate change related floods in urban poor areas: green infrastructure approach. J. Reg. City Plann. 29, 98-112. doi: $10.5614 /$ jrcp.2018.29.2.2

The Hindu (TH) (2019a). Ways to revive cascading system of Vandiyur tank discussed. Available online at: https://www.thehindu.com/news/cities/ Madurai/ways-to-revive-cascading-system-of-vandiyur-tank-discussed/ article28229208.ece (accessed December 10, 2020).

The Hindu (TH) (2019b). Madurai, a city of tanks, reels under water stress. Available online at: https://www.thehindu.com/news/cities/Madurai/maduraia-city-of-tanks-reels- under-water-stress/article29319894.ece (accessed December 10, 2020).

Times of India (ToI) (2019). MP urges Madurai corporation to supply water once in two day. Available online at: https://timesofindia.indiatimes.com/city/madurai/ mp-urges-city-corporation-to-supply-water-once-in-two-days/articleshow/ 70683545.cms (accessed December 10, 2020).

United Nations (2005). Good Practices on Strategic Planning and Management of Water Resources in Asia and the Pacific. New York, NY: United Nations Publications.

Viswanath, N. M. K., Ramachandran, S., and Reganti, H. R. (2020). Modeling and predicting the patterns of seasonal rainfall in Tamil Nadu, India 1951-2017: an UCM approach. Arab. J. Geosci. 13:226. doi: 10.1007/s12517-020-5216-0

Vörösmarty, C. J., McIntyre, P. B., Gessner, M. O., Dudgeon, D., Prusevich, A., Green, P., et al. (2010). Global threats to human water security and river biodiversity. Nature 467, 555-561. doi: 10.1038/nature09440

Wang, X. J., Zhang, J. Y., Shahid, S., Guan, E. H., Wu, Y. X., Gao, J., et al. (2016). Adaptation to climate change impacts on water demand. Mitig. Adapt. Strateg. Glob. Change 21, 81-99. doi: 10.1007/s11027-014-9 571-6

Wilk, J., and Jonsson, A. C. (2013). From water poverty to water prosperity - a more participatory approach to studying local water resources management. Water Resour. Manage. 27, 695-713. doi: 10.1007/s11269-012-0209-8

Conflict of Interest: The authors declare that the research was conducted in the absence of any commercial or financial relationships that could be construed as a potential conflict of interest.

Copyright (c) 2021 Chinnasamy and Srivastava. This is an open-access article distributed under the terms of the Creative Commons Attribution License (CC BY). The use, distribution or reproduction in other forums is permitted, provided the original author(s) and the copyright owner(s) are credited and that the original publication in this journal is cited, in accordance with accepted academic practice. No use, distribution or reproduction is permitted which does not comply with these terms. 